\title{
Potential Phytoremediation of Soil Cadmium and Zinc by Diverse Ornamental and Energy Grasses
}

\author{
Xincun Hou, ${ }^{a}$ Wenjun Teng, ${ }^{\mathrm{a}}$ Yanxia Hu, ${ }^{\mathrm{a}}$ Zhichen Yang, ${ }^{\mathrm{a}} \mathrm{Cui} \mathrm{Li},{ }^{\mathrm{a}} \mathrm{John}$ Scullion, ${ }^{\mathrm{b}}$ \\ Qiang Guo, ${ }^{a}$ and Ruilun Zheng ${ }^{\mathrm{a}, *}$
}

\begin{abstract}
The potential of 32 frequently studied ornamental and/or energy grasses and two cadmium/zinc hyperaccumulators for phytoextraction and phytostabilization was compared by their growth in a historically contaminated soil over a three-month pot experiment. Shoot and root biomasses varied by factors of 14.2 and 62.7, respectively. Mainly due to their large biomass, Napier grass (Pennisetum purpureum 'Purple') and variegated giant reed (Arundo donax var. versicolor) accumulated cadmium and zinc contents in shoots up to $109.3 \%$ and $55.4 \%$ higher, respectively, than those in the cadmium/zinc hyperaccumulators, despite their lower metal concentrations. Pennisetum purpureum 'Purple' accumulated the most zinc and the third highest cadmium in roots. Bioconcentration factors of cadmium in roots were greater than 1 for 19 grasses. The present study demonstrated that many of these grasses may be suitable for phytostabilization of soil cadmium. Arundo donax var. versicolor exhibited the most potential for phytoextraction of soil zinc, whereas Pennisetum purpureum 'Purple' was best for phytoextraction and phytostabilization of cadmium and phytostabilization of zinc. Ornamental/energy grasses may have greater potentials for soil remediation than hyperaccumulators, especially given their utility and eco-economic benefits. The considerable variation in their performance emphases the value of screening to select the most effective candidates.
\end{abstract}

Keywords: Hyperaccumulator; Heavy metal; Bioconcentration factor; Phytostabilization; Phytoextraction

Contact information: a: Research \& Development Center for Grasses and Environment, Beijing Academy of Agriculture and Forestry Sciences, Beijing, 100097 China; b: Institute of Biological, Environmental and Rural Sciences, Aberystwyth University, Wales, SY23 3DA UK; *Corresponding author: rlzheng@163.com

\section{INTRODUCTION}

Soil contamination by heavy metals is a global problem of great current interest. More than 5 million sites with an area of 20 million hectares have been contaminated by various toxic metal(loid)s globally (He et al. 2015; Liu et al. 2018). Among the toxic metal(loid)s, cadmium (Cd) is more easily taken up by crops and into the food chain due to its high mobility in soil; it is the most common toxic element (Khan et al. 2015; Zhao et al. 2015; O'Connor et al. 2018). Cadmium is considered a potential human carcinogen by the International Agency for Research on Cancer of the World Health Organization. Excessive $\mathrm{Cd}$ exposure could result in renal dysfunction, bone lesions, teratogenic effects, and other diseases (Nordberg et al. 2002; Zhang et al. 2014). Therefore, Cd is considered a critical toxic metal threatening food safety and human health (Zhao et al. 2015; Shahid et al. 2016; Huang et al. 2017; Rizwan et al. 2017). Zinc (Zn) is a common co-occurring element of $\mathrm{Cd}$, also frequently reported in connection to soil contamination (Lorenz et al. 1997; Stephan et al. 2008; He et al. 2015). 
Many remediation techniques for $\mathrm{Cd} / \mathrm{Zn}$ contaminated soils have been developed (He et al. 2015; Liu et al. 2018). Among these techniques, phytoremediation is favoured due to its advantages such as the improvement of soil physicochemical and biological properties, lower cost, and easy accessibility (Sarwar et al. 2017; Chen et al. 2019). Phytoremediation mainly involves removing or stabilizing heavy metals from/in soil using green plants, processes termed phytoextraction or phytostabilization, respectively. For phytoextraction, many $\mathrm{Cd} / \mathrm{Zn}$ hyperaccumulators have been reported (Reeves et al. 2017). However, these hyperaccumulators are usually habitat limited, slow-growing with small biomass and have shallow root systems. In addition they are hard to cultivate, making hyperaccumulators difficult to utilise in practice. Regarding phytostabilization, the mobility of heavy metals in soils can be effectively reduced via root adsorption/absorption, rhizosphere complexation, and soil and water conservation by plants to mitigate the ecological risks of contaminated sites (Erakhrumen et al. 2007; Chen et al. 2018).

Some non-hyperaccumulators such as ornamental or energy grasses have been evaluated for their heavy metal phytoextraction or phytostabilization potential because of their larger biomass, better adaptability, perennation, higher stress tolerance, use in landscape restoration, considerable metal accumulation, and utility for biofuel and absorbent production (Gong et al. 2018; Pogrzeba et al. 2018). Papazoglou et al. (2005) reported that physiological indices including biomass, plant height, and photosynthetic rates were unaffected in giant reed (Arundo donax, AD) when DTPA-extractable concentrations of $\mathrm{Cd}$ and nickel both exceeded $350 \mathrm{mg} / \mathrm{kg}$. The shoot $\mathrm{Cd}$ concentration reached up to $106 \mathrm{mg} / \mathrm{kg}$ for switchgrass when soil Cd concentration was $61.4 \mathrm{mg} / \mathrm{kg}$ (Chen et al. 2011). For $\mathrm{Cd}$ the amount accumulated in shoots of hybrid pennisetum (Pennisetum americanum $\times P$. purpureum, PAP) could reach $0.62 \mathrm{mg}$ per plant when grown in soil with a Cd concentration of $8 \mathrm{mg} / \mathrm{kg}$ (Zhang et al. 2010), in comparison to $0.24 \mathrm{mg}$ accumulated in shoots of the $\mathrm{Cd} / \mathrm{Zn}$ hyperaccumulator Alpine penny-cress (Noccaea caerulescens, NC) at $20.3 \mathrm{mg} \mathrm{Cd} / \mathrm{kg}$ in soil (Perronnet et al. 2003). The amount of $\mathrm{Zn}$ accumulation in shoots of $\mathrm{AD}$ and Amur Silvergrass (Miscanthus sacchariflorus, MS) could reach 15 and $7.1 \mathrm{mg}$ per plant, respectively, after the two grasses were grown for 60 days in soil with up to $2000 \mathrm{mg} / \mathrm{kg} \mathrm{Zn}$ addition ( $\mathrm{Li}$ et al. 2014). In addition to phytoextraction, ornamental or energy crops have the potential to stabilize soil Cd with root exudates or via their robust root systems (Guo et al. 2017; Song et al. 2018). Several grass species stabilize soil $\mathrm{Cd}$, with large root biomass and high $\mathrm{Cd}$ quantities found in roots (Golda and Korzeniowska 2016; Phusantisampan et al. 2016). However, there have been few studies comparing ornamental or energy grasses with a hyperaccumulator for phytoremediation potential and ranking their capacity for phytoextraction or phytostabilization when grown under the same conditions. Assessing the capacity of grasses to remediate $\mathrm{Cd} / \mathrm{Zn}$ contaminated soil in comparison to hyperaccumulator species would provide information about the feasibility of using ornamental or energy grasses for soil remediation, in particular given their wider economic and ecological benefits.

The present study investigated 32 species/cultivars of ornamental and/or energy grasses covering four genera for phytoremediation (phytoextraction or phytostabilization) of a historically $\mathrm{Cd}$ and $\mathrm{Zn}$ contaminated soil. Two $\mathrm{Cd} / \mathrm{Zn}$ hyperaccumulators were also included in the study for comparison. It was predicted that the high biomass of some grasses compared with the hyperaccumulators would compensate for their lower metal concentrations and that some grasses would therefore be as, or more effective, as the hyperaccumulators in soil remediation. The findings could also inform the selection of 
suitable grasses for phytoremediation in practice, the development of good grass cultivars for this purpose, and further research into mechanisms underlying remediation potential.

\section{EXPERIMENTAL}

\section{Materials}

The soil was collected from a lead-zinc mining area from Zhuzhou city, Hunan province, China $\left(27^{\circ} 52.412^{\prime} \mathrm{N}, 113^{\circ} 4.193{ }^{\prime} \mathrm{E}\right)$ and was historically heavily contaminated mainly by $\mathrm{Cd}$ and $\mathrm{Zn}$. The cadmium, $\mathrm{Zn}$, and lead $(\mathrm{Pb})$ concentrations in the soil were $160.3,6.3$, and 0.71 times respectively, the screening values of the risk control standard for soil contamination of agricultural land in China (GB/T 15618 2018). After air drying, the soil was ground and passed through a $2 \mathrm{~mm}$-sieve. Peat was used for plant cultivation before plants were transferred to contaminated soil. The physicochemical properties and heavy metal concentrations of the soil and peat are listed in Table 1.

Table 1. Physicochemical Properties of Soil and Peat Used

\begin{tabular}{|c|c|c|c|c|c|c|c|}
\hline Sample & pH & TOC (\%) & TN (\%) & $\begin{array}{c}\text { CEC } \\
(\mathbf{c m o l} / \mathbf{k g})\end{array}$ & $\begin{array}{c}\mathbf{C d}^{\star} \\
(\mathbf{m g} / \mathbf{k g})\end{array}$ & $\begin{array}{c}\mathbf{Z n} \\
(\mathbf{m g} / \mathbf{k g})\end{array}$ & $\begin{array}{c}\mathbf{P b} \\
(\mathbf{m g} / \mathbf{k g})\end{array}$ \\
\hline Soil & 7.2 & 1.67 & 0.13 & 20.7 & 48.1 & 1575 & 84.6 \\
\hline Peat & 5.1 & 35.7 & 2.4 & - & 0.17 & 30.2 & 17.5 \\
\hline
\end{tabular}

${ }^{*}$ Risk screening values of $\mathrm{Cd}, \mathrm{Zn}$ and $\mathrm{Pb}$ in Risk Control Standard for Soil Contamination of Agricultural Land in China (GB15618-2018) are 0.3, 250 and $120 \mathrm{mg} / \mathrm{kg}$, respectively, at soil $\mathrm{pH}$ 6.5-7.5

A total of 34 herbaceous plants including 32 different species/cultivars of ornamental and/or energy grasses covering four genera and two $\mathrm{Cd} / \mathrm{Zn}$ hyperaccumulators were collected. The common names, Latin names, and abbreviations are listed in Table 2. Pennisetum grasses included 13 species/cultivars. The PSI, PAP, PP, and PPP species/cultivars are characterized by large biomass and are mainly usable as energy grasses; the other nine species/cultivars are often used for ornamental purposes. The eight cultivars of Panicum virgatum and nine species/cultivars of Miscanthus investigated are mainly considered as energy grasses but are often applied in landscape restoration. All 32 grasses are routinely planted and managed for energy production, landscape improvement, or soil and water conservation. Noccaea caerulescens and ILC are considered as $\mathrm{Cd}$ and $\mathrm{Zn}$ hyperaccumulators and Cd hyperaccumulators, respectively (McGrath and Zhao 2003; Han et al. 2007; Guo et al. 2017; Reeves et al. 2017).

\section{Plant Cultivation}

The Cd hyperaccumulator ILC was propagated through tiller separation, and the 32 grasses were grown from cuttings. Regarding the use of cuttings, uniform rhizomes each with one intact bud were selected, and stalks were clipped with pruning shears to a uniform size (7-cm height) (Fig. S1). For tiller separation, ramets were clipped to get uniform seedlings (7-cm height, 4-cm root length) after stock plants were divided, and planted into peat (Fig. S2). All ramets and rhizomes were cultivated in the prepared peat and irrigated with deionized water regularly. All rhizomes or ramets were planted on the same day. 
Table 2. Plant Materials Used in the Present Study

\begin{tabular}{|c|c|c|c|c|}
\hline No. & Common name & Latin Name & Abbreviation & Origin \\
\hline 1 & Alpine penny-cress & Noccaea caerulescens & $\mathrm{NC}$ & Ganges, Southern France \\
\hline 2 & Chinese Small Iris & Iris lactea var. chinensis & ILC & Zhaosu county, Ylli prefecture, Xinjiang province, China \\
\hline 3 & Napier grass & Pennisetum purpureum 'Purple' & PPP & Guangdong province, China \\
\hline 4 & Napier grass & P. purpureum & PP & Guangdong province, China \\
\hline 5 & King grass & P. sinese & PSI & Introduced from Colombia in 2004 \\
\hline 6 & Hybrid pennisetum & $P$. americanum $\times P$. purpureum & PAP & Introduced from Colombia in 2004 \\
\hline 7 & Changsui fountain grass & $P$. alopecuroides 'Changsui' & PAC & Bred by RDCGE* \\
\hline 8 & Liren fountain grass & P. alopecuroides 'Liren' & PAL & Bred by RDCGE \\
\hline 9 & Ziguang fountain grass & P. alopecuroides 'Ziguang' & PAZ & Bred by RDCGE \\
\hline 10 & Baijian fountain grass & P. alopecuroides 'Baijian' & PAB & Bred by RDCGE \\
\hline 11 & Aizhu fountain grass & $P$. alopecuroides 'Aizhu' & PAA & Bred by RDCGE \\
\hline 12 & Rubrum fountain grass & P. setaceum 'Rubrum' & PSR & Yunnan province, China \\
\hline 13 & Feathertop fountain grass & P. villosum R. Br. ex Fresen. & PVR & Introduced from Spain in 2003 \\
\hline 14 & Oriental fountain grass & P. orientale & PO & Introduced from Canada in 2005 \\
\hline 15 & Crimson fountain grass & $P$. setaceum & PSE & Introduced from Italy in 2007 \\
\hline 16 & Blackwell switchgrass & Panicum virgatum 'Blackwell' & PVB & Northern Oklahoma $37^{\circ}$, USA $\left(U^{*}\right)$ \\
\hline 17 & Cave in rock switchgrass & P. virgatum 'Cave in rock' & PVC & South Illinois $38^{\circ}$, USA $(U)$ \\
\hline 18 & Forestburg switchgrass & P. virgatum 'Forestburg' & PVF & South Dakota $44^{\circ}$, USA (U) \\
\hline 19 & New York switchgrass & P. virgatum 'New York' & PVN & New York $40^{\circ}$, USA (L) \\
\hline 20 & Alamo switchgrass & P. virgatum 'Alamo' & PVA & South Texas $28^{\circ}$, USA (L) \\
\hline 21 & Kanlow switchgrass & P. virgatum 'Kanlow' & PVK & Central Oklahoma $35^{\circ}$, USA (L) \\
\hline 22 & Pathfinder switchgrass & P. virgatum 'Pathfinder' & PVP & Nebraska/Kansas $40^{\circ}$, USA (U) \\
\hline 23 & Trailblazer switchgrass & $P$. virgatum 'Trailblazer' & PVT & Nebraska $40^{\circ}$, USA (U) \\
\hline 24 & Changxu Miscanthus & Miscanthus sinensis 'Changxu' & MSC & Bred by RDCGE \\
\hline 25 & Xianxu Miscanthus & M. sinensis 'Xianxu' & MSX & Bred by RDCGE \\
\hline 26 & Hongsui Miscanthus & M. sinensis 'Hongsui' & $\mathrm{MSH}$ & Bred by RDCGE \\
\hline 27 & Mihua Miscanthus & M. sinensis 'Mihua' & MSM & Bred by RDCGE \\
\hline 28 & Gold Bar Miscanthus & M. sinensis 'Gold Bar' & MSG & Bred by RDCGE \\
\hline 29 & Zebrinus Miscanthus & M. sinensis 'Zebrinus' & MSZ & Introduced from Canada in 2006 \\
\hline 30 & Yaku Jima Miscanthus & M. sinensis 'Yaku Jima' & MSY & Introduced from Canada in 2006 \\
\hline 31 & Giant Miscanthus & M. giganteus & MG & Introduced from Germany in 2006 \\
\hline 32 & Amur Silvergrass & M. sacchariflorus & MS & Shanxi province, China \\
\hline 33 & Giant Reed & Arundo donax & $A D$ & Jiangsu province, China \\
\hline 34 & Variegated Giant Reed & A. donax var. versicolor & ADV & Taiwan province, China \\
\hline
\end{tabular}


After 3 weeks growth, uniform seedlings were selected and washed thoroughly with deionized water to remove attached particles (Fig. S3). Afterward, these seedlings were transplanted into the contaminated soils and clipped to 7-cm height again.

Seed propagation was used for NC. After soaking in $30 \% \mathrm{H}_{2} \mathrm{O}_{2}$ solution for 30 min and thorough washing with deionized water, the seeds were placed in petri dish with moist filter paper at $25{ }^{\circ} \mathrm{C}$ in the dark for 2 weeks (Fig. S4). Then, the germinated seeds were transferred to vermiculite for further cultivation, maintaining moisture via deionized water irrigation. After cotyledons were totally developed, they were watered with a nutrient solution. Seedlings were transplanted to peat and irrigated with deionized water after growing in vermiculite for 5 months. After 3 weeks' growth in peat, uniform seedlings were selected, washed and transplanted into contaminated soils on the same day as other herbaceous plants.

After being mixed thoroughly with fertilizers to avoid any nutrient limitation, the soil was potted $(1.3 \mathrm{~kg}$ per pot: top/bottom diameter $15 \mathrm{~cm} / 11 \mathrm{~cm}$, depth $13 \mathrm{~cm}$ ). Fertilizer inputs consisted of $200 \mathrm{mg}$ nitrogen, $150 \mathrm{mg}$ phosphorus, and $60 \mathrm{mg}$ magnesium as urea, $\mathrm{KH}_{2} \mathrm{PO}_{4}$, and $\mathrm{MgSO}_{4} \cdot 7 \mathrm{H}_{2} \mathrm{O}$, respectively, per kilogram soil (Fig. S5). One seedling was planted in contaminated soil per pot. Each plant species/cultivar was replicated four times. Pots were arranged in a randomized complete block design in a greenhouse with ambient lighting, $70 \%$ to $80 \%$ relative humidity and with 20 to $35^{\circ} \mathrm{C} / 15$ to $20^{\circ} \mathrm{C}$ day/night time temperatures. Deionized water was added according to regular weighing to hold soil moisture content at 60 to $70 \%$ of the water holding capacity.

After 3 months' growth, plant shoots were cut above soil and roots were removed carefully from soils by gentle sieving. Shoots and roots were washed thoroughly with deionized water, dried at $105^{\circ} \mathrm{C}$ for $0.5 \mathrm{~h}$ then at $70^{\circ} \mathrm{C}$ for $48 \mathrm{~h}$, and then weighed. Roots were scanned into WinRhizo software (V5.0, Regent Instruments, Quebec, Canada) for the estimation of root length (RL) and root surface area (RSA) before drying (Zheng et al. 2013).

\section{Analytical Methods}

The physicochemical properties of soil and peat used were analyzed as described by $\mathrm{Lu}$ (2000). The $\mathrm{pH}$ values of soil and peat were measured in suspensions of solid substrate and water at a ratio of 1:2.5 using a $\mathrm{pH}$ meter. Total organic carbon and total nitrogen in soil and peat were determined using potassium dichromate oxidation and potassium sulfate oxidation-ultraviolet spectrophotometry methods. The cation exchange capacity of soil was analyzed using the ammonium acetate method. Soil and peat samples were finely ground $(<0.149 \mathrm{~mm})$ then digested with concentrated $\mathrm{HCl}-\mathrm{HNO}_{3}-\mathrm{HClO}_{4}$ (3:1:1) to assay total metal concentrations (Zheng et al. 2013).

Dried shoot and root samples were ground and digested using concentrated $\mathrm{HNO}_{3}$ in a microwave digestion system (Guo et al. 2017). Cadmium and $\mathrm{Zn}$ in digestion solutions were analyzed using inductively coupled plasma mass spectroscopy (ICP-MS, Agilent 7500, Santa Clara, CA, USA). Blanks and certified reference materials (CRM) GBW07603 (bush twigs and leaves) and GBW07401 (soils) were included for quality assurance. The recovery ratios for reference samples ranged from 87 to $112 \%$.

\section{Data Analysis}

The translocation factor (TF), calculated as the ratio of metal concentration in plant shoot to that in root, describes the movement of metals from root to shoot with implications for phytoextraction potential (Zheng et al. 2017). The bioconcentration 
factor of shoots (BCFS) and of roots (BCFR), defined as the ratios of metal concentrations in plant shoots and roots to that in soil respectively, indicate the potential of a plant for metal accumulation in shoot and root respectively at a given level of metal contamination (McGrath and Zhao 2003; Zheng et al. 2017). Metal amounts accumulated in plant shoot and root were equal to the products of their metal concentration and biomass. Uptake efficiency (UE) was calculated as the ratio of the metal amount in the whole plant, including shoot and root, to root dry weight.

All data that met the normal distribution condition were analyzed with one-way analysis of variance. The least significant difference test $(p<0.05)$ was used for mean comparisons for data that met the conditions of homogeneous variance, while Tamhane's T2 test was used if equal variance of the data was not assumed. Data with a non-normal distribution were analyzed with the Kruskal-Wallis test. Pearson and Spearman analysis was conducted to examine the relationships between $\mathrm{Cd}$ and $\mathrm{Zn}$ in shoot and root concentrations, TFs and UEs. These tests were also used to study relationships between $\mathrm{Cd}$ and $\mathrm{Zn}$ accumulation and rooting parameters. Multiple linear regressions using a stepwise method were employed to examine relationships between $\mathrm{Cd} / \mathrm{Zn}$ concentrations in shoot or root and the rooting parameters. All statistical analysis was performed using SPSS 22.0 software (IBM, Armonk, New York, USA).

\section{RESULTS AND DISCUSSION}

\section{Plant Growth}

After 3 months' growth in the contaminated soil, the 32 grasses did not exhibit visual toxicity symptoms except for MSY, which ceased growth after two weeks. Among the other grasses, the six with the largest shoot dry weight (SW) were PSI, PAP, PP, PPP, ADV, and AD, whose SW was 10.7 to 14.2 times that of PAB with the smallest SW $(p<$ $0.05)$ (Fig. 1a). The three grasses with the largest root dry weight (RW) were PVR, PP and PSI, 45.9 to 62.7 times that of NC with the smallest RW ( $p<0.05)$ (Fig. 1b).

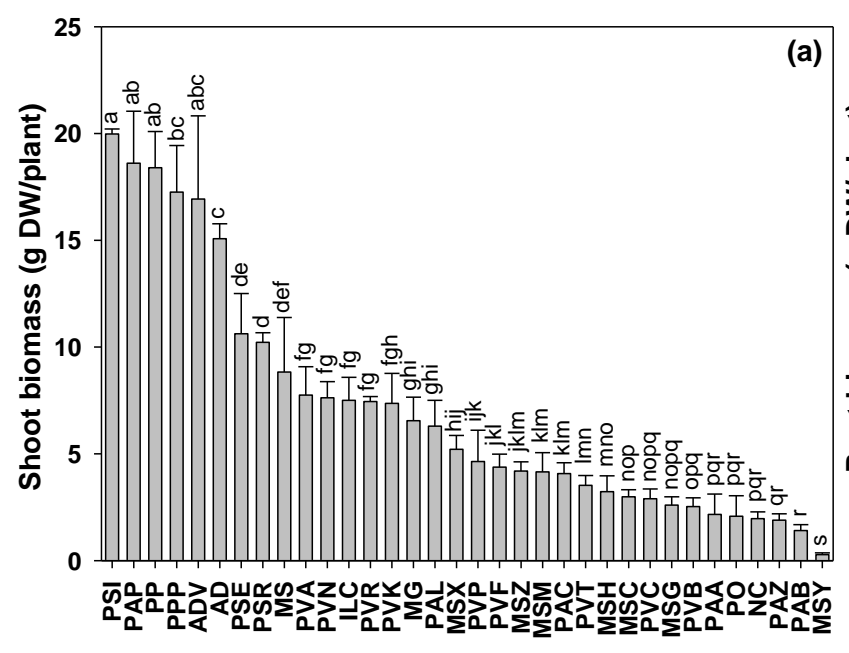

Plant species

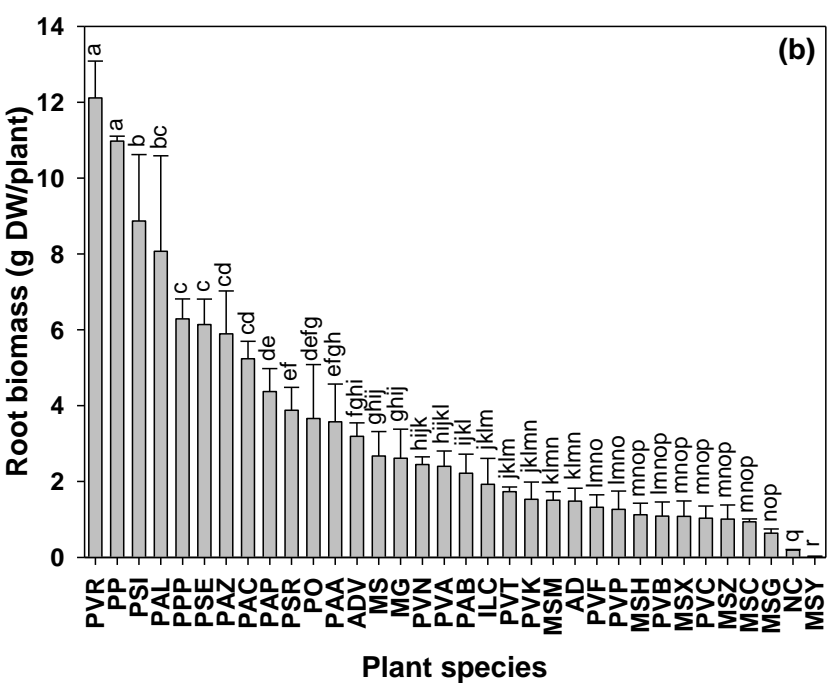

Plant species

Fig. 1. Shoot (a) and root (b) dry weight of 32 grasses and 2 hyperaccumulators (mean $\pm S D, n=$ 4). Means with a common letter above columns do not differ at $p<0.05$. 
Considering findings within each genus or species, for Pennisetum there were slight differences in SW between PSI, PAP, PP, and PPP, yet RW differences were larger in the order PP > PSI > PPP > PAP with a 2.5 times range difference $(p<0.05)$. Among the other nine species/cultivars, PSE had the largest SW, 7.5 times that of PAB with the lowest SW ( $p<0.05)$. The RW of PAB was $81.7 \%$ less than that of PVR $(p<0.05)$ (Fig. 1b). For Panicum virgatum, the eight cultivars had high variability, the largest PVA being 3.1 times the SW of the smallest. P. virgatum 'New York' had the largest RW 2.4 times that of PVC the smallest $(p<0.05)$. Biomass of the three lowland cultivars (PVA, PVK, PVN) was generally greater than that of the five upland cultivars (Fig. 1a, b). Among nine species/cultivars of Miscanthus, excluding MSY, SW of MS was largest following by MG, and MSG had the smallest SW. Shoot dry weight of MS was 3.4 times that of MSG. RW varied by a factor of 4.2 and the sequence of RW was similar to that of shoots. Biomass of M. sinensis was generally smaller than that of MG and MS (Fig. 1a, b). There was no significant difference in SW between AD and ADV, yet RW for ADV was 2.2 times that for $\mathrm{AD}(p<0.05)$. Iris lactea var. chinensis and $\mathrm{NC}$ had an intermediate and a small biomass respectively, relative to all herbaceous plants (Fig. 1).

\section{Cd and $\mathrm{Zn}$ Concentrations for Various Plants}

The shoot Cd concentration of NC $(475 \mathrm{mg} / \mathrm{kg})$ was far greater (10.0 to 297 times) that of the 32 grasses $(1.6$ to $47.6 \mathrm{mg} / \mathrm{kg})(p<0.05)$. Iris lactea var. chinensis had the second highest shoot $\mathrm{Cd}$ concentration statistically similar to that of PPP and 1.3 to 33.1 times of the other 31 grasses $(p<0.05)$. The two grasses with highest shoot $\mathrm{Cd}$ concentrations were PPP and PAP, 25.1 to 29.8 times of that for PAC with the lowest Cd concentration $(p<0.05$ ) (Fig. 2a). M. sinensis 'Yaku Jima' that showed distinct toxicity symptoms had the highest $\mathrm{Cd}$ concentration in roots, followed by NC and MSX. The lowest root $\mathrm{Cd}$ concentration found was for PO, followed by PAZ and PAL. Excluding MSY, root Cd concentrations varied by a factor of 12.3 among grasses (Fig. 2b).
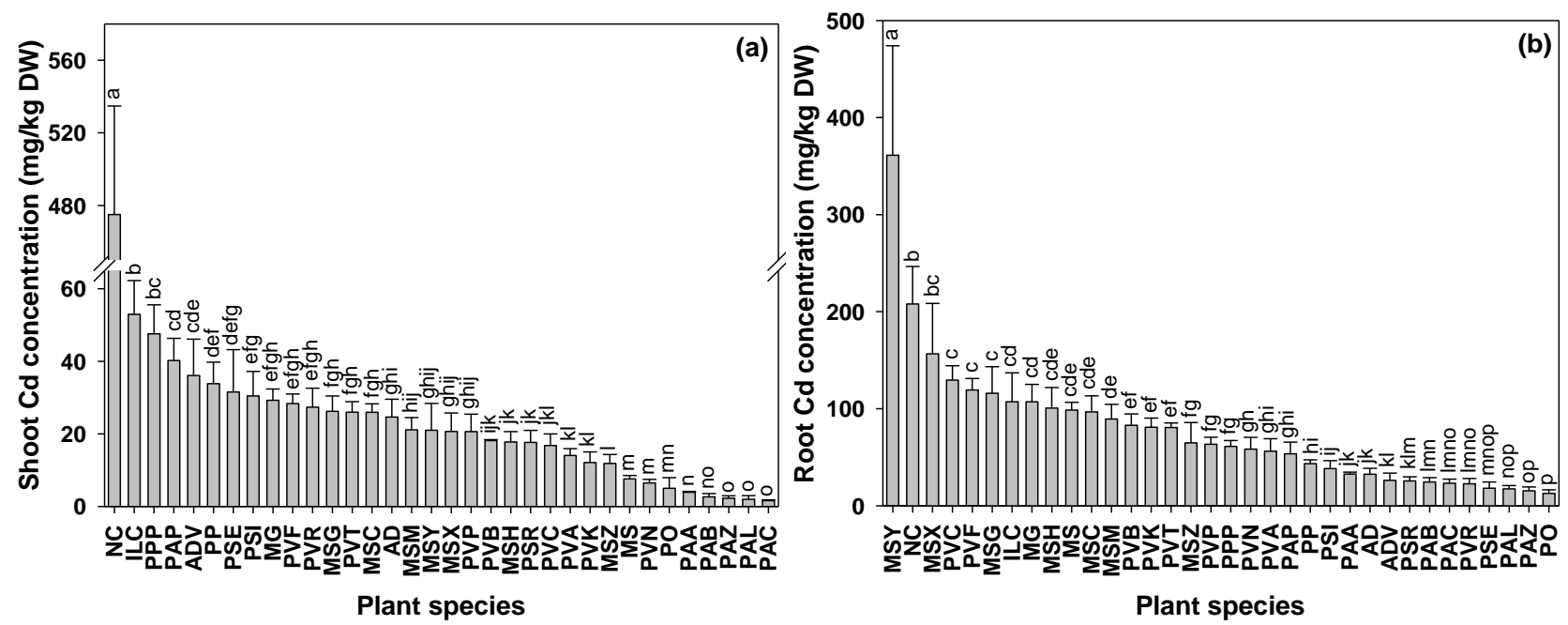

Fig. 2. Cadmium concentration in shoot (a) and root (b) of 32 grasses and 2 hyperaccumulators (mean $\pm S D, n=4$ ). Means with a common letter above columns do not differ at $p<0.05$.

Considering species/cultivars of each genus/species, shoot $\mathrm{Cd}$ concentrations for Pennisetum, Miscanthus, and Panicum virgatum varied by factors of 29.8, 3.9 and 4.4 ( $p$ $<0.05)$ respectively, and with PPP, MG, PVF having the highest shoot Cd concentrations 
(Fig. 2a). Root Cd concentrations among species/cultivars of Pennisetum, Miscanthus, and Panicum virgatum varied by factors of $4.8,5.6$, and 2.3 , respectively ( $p<0.05)$, with PPP, MSY, and PVC having the highest concentration. There was no significant difference in root $\mathrm{Cd}$ concentrations between $\mathrm{AD}$ and $\mathrm{ADV}$, but there was a higher shoot $\mathrm{Cd}$ concentration in $\mathrm{ADV}(p<0.05)$. Root $\mathrm{Cd}$ concentrations of the thirteen species/cultivars of Pennisetum genus were generally low in the ranking of the grasses. The lowland cultivars (PVA, PVK, PVN) had generally lower shoot Cd concentrations than the upland cultivars for Panicum virgatum. Root $\mathrm{Cd}$ concentrations of the nine species/cultivars of Miscanthus generally ranked high among the grasses (Fig. 2b).

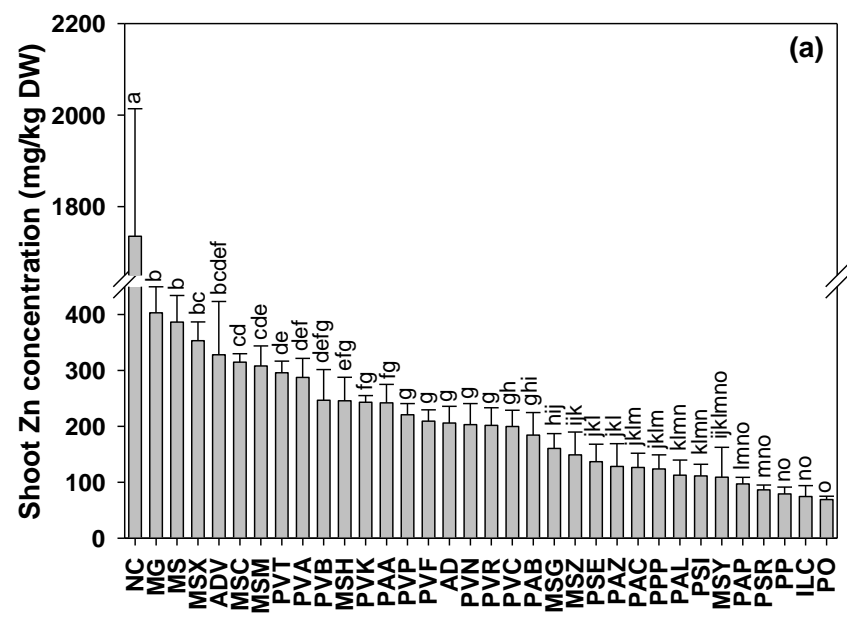

Plant species

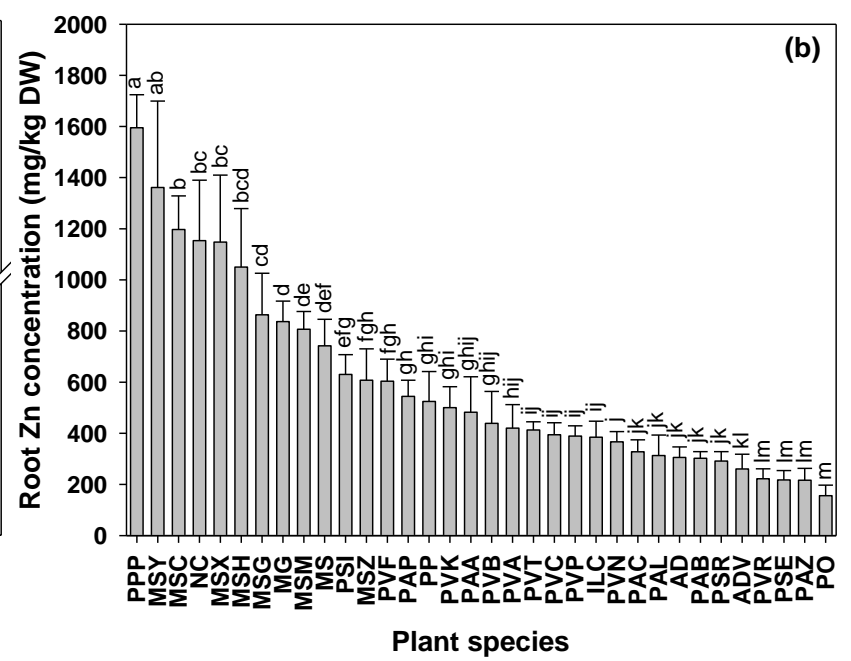

Fig. 3. Zinc concentration in shoot (a) and root (b) of 32 grasses and 2 hyperaccumulators (mean $\pm \mathrm{SD}, \mathrm{n}=4$ ). Means with a common letter above columns do not differ at $p<0.05$.

Among grasses, MG had the highest shoot Zn concentration, followed by MS and MSX, with PO having the lowest concentration. Shoot Zn concentration of MG was 5.9 times that of PO. Shoot $\mathrm{Zn}$ concentration of NC was far higher than in the grasses, 4.3 times that of MG $(p<0.05)$. Though it had high shoot $\mathrm{Cd}$ concentration, ILC had the second lowest shoot Zn concentration (Fig. 3a). Root Zn concentrations varied by a factor of 11.2 among the grasses. The highest root $\mathrm{Zn}$ concentration was found in PPP, followed by MSY and MSC. P. orientale had the lowest $\mathrm{Zn}$ concentration in roots (Fig. 3b).

Within each genus/species, shoot Zn concentrations for Pennisetum, Miscanthus, and Panicum virgatum varied by factors of 3.5, 3.7, and 1.5 respectively $(p<0.05)$, with PAA, MG, PVT having the highest Zn concentrations in shoots (Fig. 3a). The root Zn concentrations within each genus/species for Pennisetum, Miscanthus, and Panicum virgatum varied by factors of 10.2, 2.2, and 1.7 respectively $(p<0.05)$, with PPP, MSY, and PVF having the highest $\mathrm{Zn}$ concentrations (Fig. 3b). There was no significant difference in root $\mathrm{Zn}$ concentrations between $\mathrm{ADV}$ and $\mathrm{AD}$, though shoot $\mathrm{Zn}$ concentration of ADV was 59.5\% higher than that of AD ( $p<0.05)$. Root $\mathrm{Zn}$ concentrations of the nine species/cultivars of Miscanthus were generally high in the ranking of the grasses (Fig. 3b).

\section{Cd and Zn Amounts Accumulated in Various Plants}

Total $\mathrm{Cd}$ accumulations in shoots of NC, PPP, and PAP did not differ significantly $(p<0.05)$ and were larger than those of the other grasses. Grasses such as 
PPP, PAP, PP, PSI, and ADV accumulated $49.9 \%$ to $109.3 \%$ more $\mathrm{Cd}$ than the hyperaccumulator ILC. Shoot Cd contents varied markedly among all 34 plants by a factor of 318, and among the grasses by a factor of 281 (Fig. 4a). The largest Cd amount in roots was accumulated by PP, followed by PSI and PPP. Notably, the second lowest root $\mathrm{Cd}$ accumulation was in NC. Cadmium accumulated in roots of PP was 12.0 times that of NC $(p<0.05)$ (Fig. 4b).
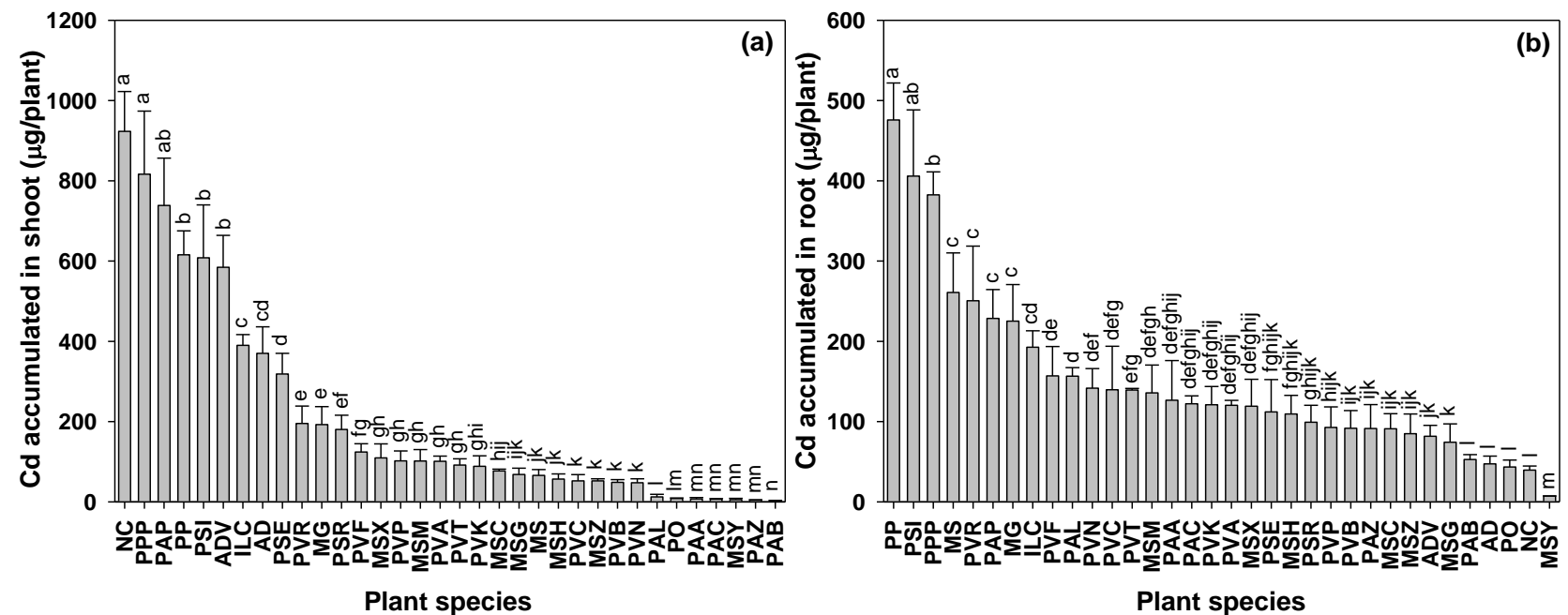

Fig. 4. Cadmium amount in shoot (a) and root (b) of 32 grasses and 2 hyperaccumulators (mean $\pm \mathrm{SD}, \mathrm{n}=4$ ). Means with a common letter above columns do not differ at $p<0.05$.

Considering species/cultivars of each genus/species, shoot $\mathrm{Cd}$ amounts for Pennisetum, Miscanthus, and Panicum virgatum varied by factors of 281, 33.5 and 2.6, respectively ( $p<0.05$ ), with PPP, MG, PVF having the highest Cd amounts in shoots. Root Cd amounts in species/cultivars of each genus/species of Pennisetum, Miscanthus, and Panicum virgatum varied by factors of 10.9, 36.1, and $1.7(p<0.05)$, respectively, with PP, MS, PVF having the highest $\mathrm{Cd}$ amounts in root. Total $\mathrm{Cd}$ amounts in shoots and roots of ADV were $57.9 \%$ and $72.5 \%$ greater than those of AD respectively ( $p<$ 0.05). Shoot $\mathrm{Cd}$ amounts of $\mathrm{ADV}$ and $\mathrm{AD}$ ranked high among the grasses but root $\mathrm{Cd}$ amounts ranked lowly.

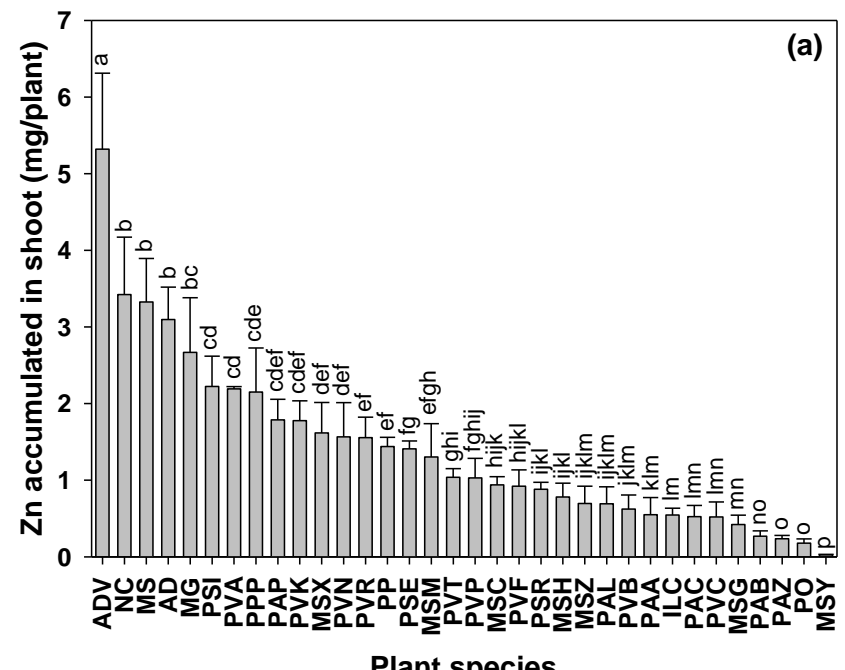

Plant species

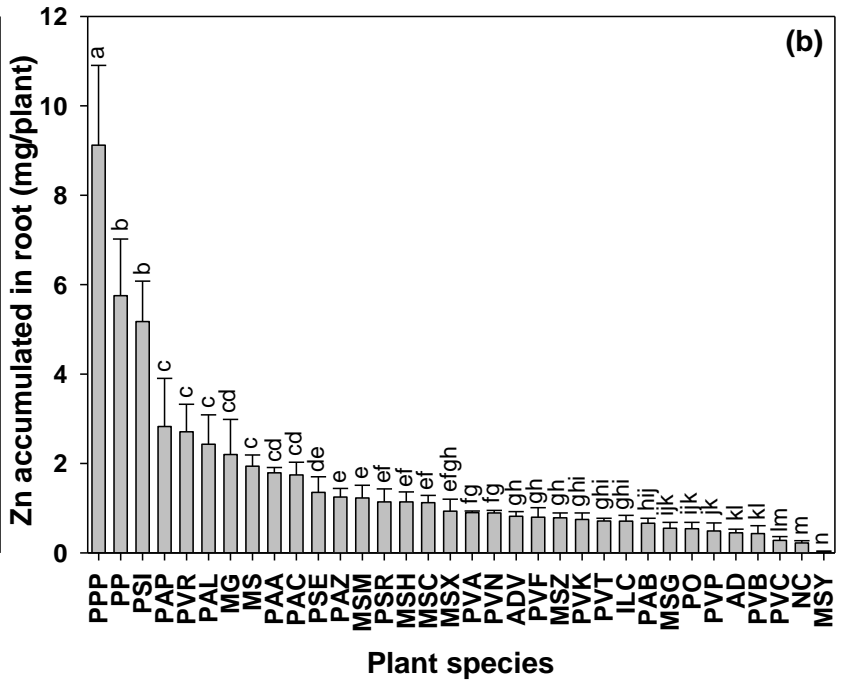

(b) 
Fig. 5. Zinc amount accumulated in shoot (a) and root (b) of 32 grasses and 2 hyperaccumulators (mean $\pm \mathrm{SD}, \mathrm{n}=4$ ). Means with a common letter above columns do not differ at $p<0.05$.

Regarding Zn amounts in shoots, it was largest for ADV, followed by NC, MS, and $\mathrm{AD}$. Shoot $\mathrm{Zn}$ amount in $\mathrm{ADV}$ was $55.4 \%$ greater than that of $\mathrm{NC}(p<0.05) . M$. sinensis 'Yaku Jima' accumulated the smallest amount of $\mathrm{Zn}$ in shoots, followed by PO and PAZ. Shoot Zn amounts varied by a factor of 29.9 between ADV and PO (Fig. 5a). Pennisetum purpureum 'Purple' accumulated the largest $\mathrm{Zn}$ amount in roots, followed by PP, PSI, and PAP. The smallest amount of $\mathrm{Zn}$ in roots was accumulated by MSY, followed by NC and PVC. Root Zn accumulated by PPP was 41.1 times of that by NC ( $p$ $<0.05$ ) (Fig. 5b).

Regarding species/cultivars of each genus/species, shoot $\mathrm{Zn}$ amounts for Pennisetum, Miscanthus, and Panicum virgatum varied by factors of 12.1, 122, and 4.2 ( $p$ $<0.05$ ), with PPP, MS, PVA having the highest Zn amounts in shoots (Fig. 5a). Root Zn amounts in species/cultivars for Pennisetum, Miscanthus, and Panicum virgatum varied by factors of 16.8, 77.1, and 3.2 ( $p<0.05)$, with PPP, MG, PVA having the highest $\mathrm{Zn}$ amounts in roots (Fig. 5b). Both ADV and AD accumulated high amounts of $\mathrm{Zn}$ in shoots but not in roots. Zinc amounts in shoots and roots of ADV were $71.8 \%$ and $82.9 \%$ greater than those of $\mathrm{AD}$, respectively $(p<0.05)$. Zinc amounts accumulated in roots of species/cultivars of Pennisetum ranked high (1.1 to $9.1 \mathrm{mg} / \mathrm{plant}$ ) except for PAB and PO (0.54 to $0.66 \mathrm{mg} / \mathrm{plant}$ ) among the grasses. Lowland cultivars of Panicum virgatum (PVA, PVK, PVN) accumulated more $\mathrm{Zn}$ in shoots than upland ones in general.

\section{BCFS, BCFR, TF, and UE of Cd and Zn for Various Plants}

Only NC had a BCFS of Cd markedly greater than 1. The BCFSs of Cd for ILC and PPP were slightly higher than 1. Noccaea caerulescens had a BCFS 9.0 and 9.5 times those of ILC and PPP respectively. Bioconcentration factors of shoots varied by a factor of 31.2 among the grasses (Fig. 6a). The BCFSs of Cd for various species/cultivars of each of the genus/species of Pennisetum, Miscanthus, Panicum virgatum, and Arundo donax ranged from 0.03 to $1.04,0.25$ to $0.61,0.13$ to 0.59 , and 0.51 to 0.75 , respectively. There were 19 grasses whose BCFRs were larger than 1. Noccaea caerulescens had the highest BCFR (4.3), 3.9 times that of the PAP BCFR (1.1) $(p<0.05)$ (Fig. 6b). The bioconcentration factors of roots of $\mathrm{Cd}$ for various species/cultivars of Pennisetum, Miscanthus, Panicum virgatum, and Arundo donax ranged from 0.27 to $1.27,1.35$ to $7.51,1.17$ to 2.69 , and 0.54 to 0.68 , with $15.4 \%, 100 \%, 100 \%$, and $0 \%$ of species/cultivars having a BCFR exceeding 1 respectively.

Among the plants tested, only NC had a BCFS of $\mathrm{Zn}$ (1.1) exceeded 1, the grasses having low BCFSs (0.04 to 0.26). The Cd hyperaccumulator ILC had the second lowest BCFS for Zn. Only PPP had a Zn BCFR (1.01) higher than 1, with the others $(0.10$ to 0.86) less than 1 (Fig. 7).

The TFs of Cd for NC, PSE, ADV and PVR were larger than 1, and not significantly different; that for NC was 1.4 to 38.7 times those for the grasses $(p<0.05)$. The TF of Cd for ILC was lower than 1. M. sinensis 'Yaku Jima', which showed severe toxicity symptoms had the lowest TF, followed by PAC and PAL. Cadmium TFs of species/cultivars for Pennisetum, Miscanthus, Panicum virgatum, and Arundo donax varied from 0.07 to $1.72,0.06$ to $0.28,0.13$ to 0.32 , and 0.76 to 1.38 respectively. For $\mathrm{Zn}$, only NC and ADV had TFs larger than 1, and these TFs did not differ significantly. Zinc TF for MSY was the smallest followed by PPP, then PP. The TFs of Zn among the 34 plants varied by a factor of 25.0 and among the 32 grasses by 20.6 (Table 3). Zinc TFs of 
various species/cultivars for Pennisetum, Miscanthus, Panicum virgatum, and Arundo donax ranged from 0.08 to $0.92,0.06$ to $0.52,0.35$ to 0.72 and 0.67 to 1.3 , respectively. Miscanthus and Arundo donax ranked low and high in TFs among grasses respectively, for both $\mathrm{Cd}$ and $\mathrm{Zn}$.

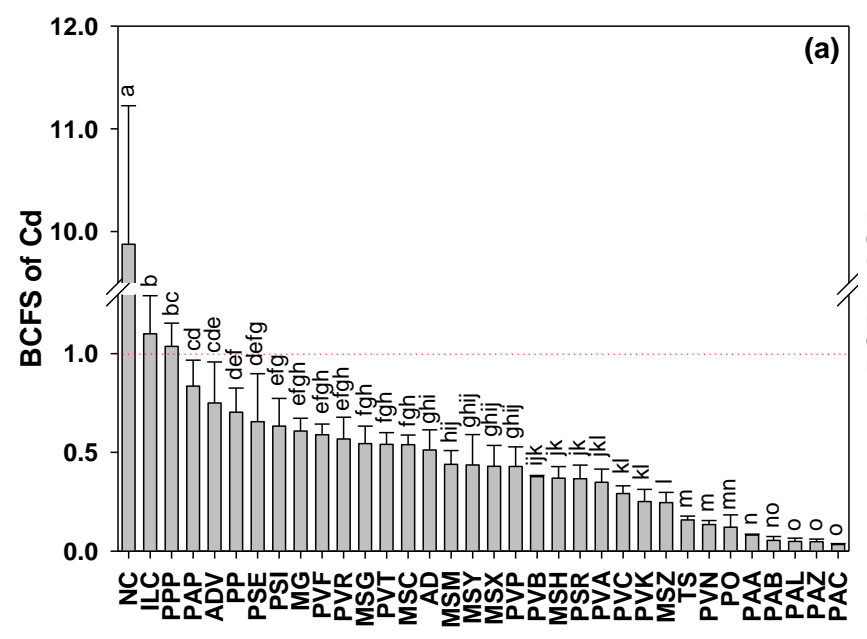

Plant species

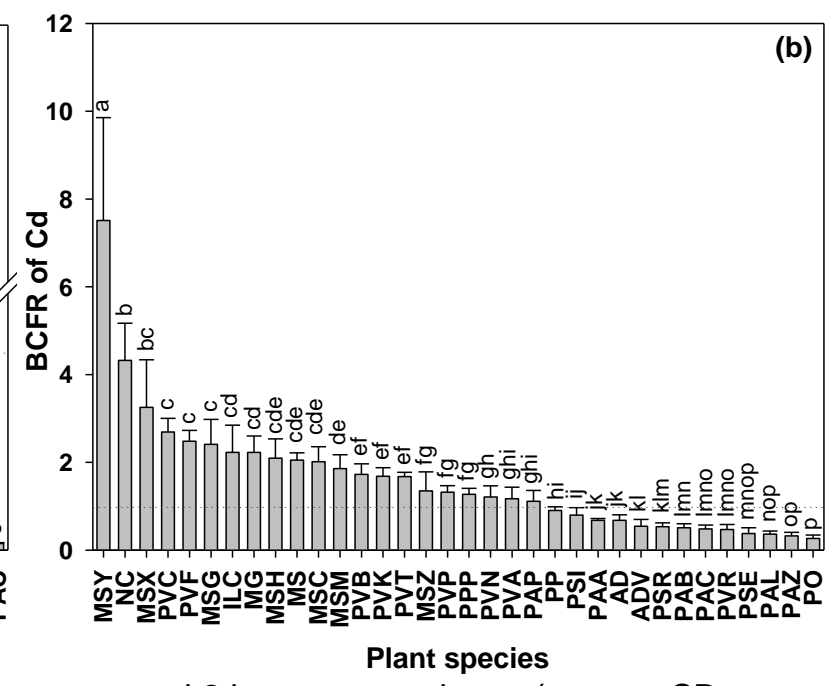

Plant species

Fig. 6. The BCFS (a) and BCFR (b) of Cd for 32 grasses and 2 hyperaccumulators (mean $\pm S D$, $\mathrm{n}=4)$. Means with a common letter above columns do not differ at $p<0.05$.
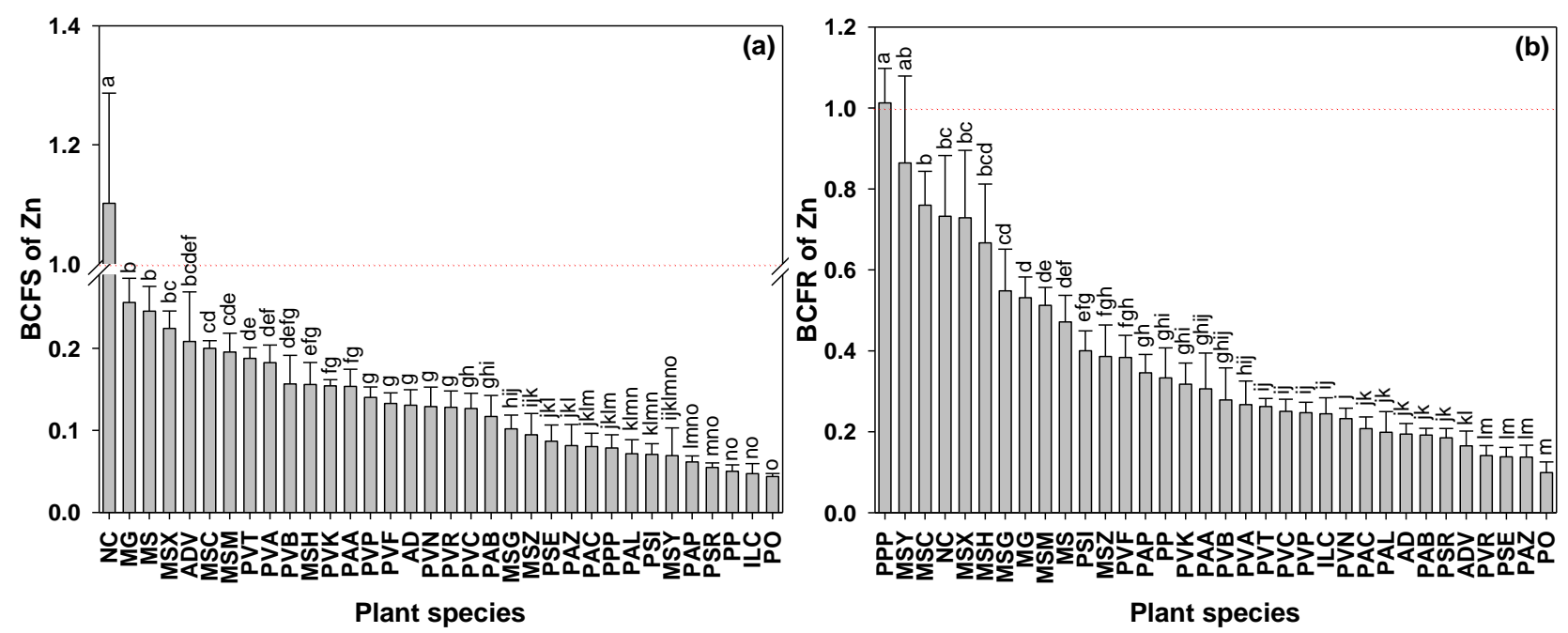

Fig. 7. The BCFS (a) and BCFR (b) of Cd for 32 grasses and 2 hyperaccumulators (mean $\pm S D$, $\mathrm{n}=4)$. Means with a common letter above columns do not differ at $p<0.05$.

Uptake efficiencies (UEs) were calculated to compare the $\mathrm{Cd} / \mathrm{Zn}$ uptake capacity of plant roots based on $\mathrm{Cd} / \mathrm{Zn}$ amount accumulated in the whole plant. The UEs of $\mathrm{Cd}$ and $\mathrm{Zn}$ for $\mathrm{NC}$ were respectively 10.7 to 327 and 6.9 to 96.6 times those of the grasses ( $p$ $<0.05$ ) (Table 3). Iris lactea var. chinensis had the third largest UE of $\mathrm{Cd}$ after NC and MSY, 21.5 times that of PO $(p<0.05)$, and had an intermediate UE for Zn. Among the grasses, PO had the lowest UE for Cd and Zn. For the UE of Zn, MSX had the highest value of the remaining grasses, 13.8 times that of $\mathrm{PO}(p<0.05)$.

In order to ascertain whether $\mathrm{Cd}$ and $\mathrm{Zn}$ behave in a similar fashion in uptake by roots and translocation from root to shoot, correlations of shoot concentrations, root concentrations, UE and TF between $\mathrm{Cd}$ and $\mathrm{Zn}$ were analyzed; this analysis also had the 
potential to provide some basis for proposing mechanisms for the variations observed. Among the 32 grasses, root $\mathrm{Cd}$ concentrations were positively correlated to root $\mathrm{Zn}$ concentrations $(p<0.0001)$ (Fig. 8b), but this was not the case for shoots (Fig. 8a). The UEs of Cd were positive correlated to those of $\mathrm{Zn}(p<0.0001)$ (Fig. 8c) but their TFs were not (Fig. 8c, d).

Table 3. TF and UE of $\mathrm{Cd}$ and $\mathrm{Zn}$ for Various Grasses and 2 Hyperaccumulators

\begin{tabular}{|c|c|c|c|c|c|}
\hline \multirow{2}{*}{ No. } & \multirow{2}{*}{$\begin{array}{c}\text { Plant } \\
\text { species }\end{array}$} & \multicolumn{2}{|r|}{ TF } & \multicolumn{2}{|c|}{ UE (mg/g root) } \\
\hline & & $\mathrm{Cd}$ & $\mathrm{Zn}$ & $\mathrm{Cd}$ & $\mathrm{Zn}$ \\
\hline 1 & $\mathrm{NC}$ & $2.34 \pm 0.45 a$ & $1.52 \pm 0.15 \mathrm{a}$ & $5.02 \pm 0.54 \mathrm{a}$ & $18.9 \pm 3.97 \mathrm{a}$ \\
\hline 2 & ILC & $0.51 \pm 0.06 \mathrm{e}$ & $0.19 \pm 0.02 r s$ & $0.33 \pm 0.10 b$ & $0.70 \pm 0.19 \mathrm{kmo}$ \\
\hline 3 & PPP & $0.78 \pm 0.13 d$ & $0.08 \pm 0.01 \mathrm{t}$ & $0.19 \pm 0.03$ bcde & $1.82 \pm 0.43$ cdef \\
\hline 4 & PAP & $0.84 \pm 0.25 \mathrm{~d}$ & $0.18 \pm 0.02 \mathrm{rs}$ & $0.23 \pm 0.05 b c$ & $1.09 \pm 0.38 \mathrm{hijkl}$ \\
\hline 5 & $\mathrm{PSI}$ & $0.80 \pm 0.13 d$ & $0.17 \pm 0.02 \mathrm{~s}$ & $0.11 \pm 0.01 \mathrm{hij}$ & $1.09 \pm 0.39$ hijkl \\
\hline 6 & PP & $0.78 \pm 0.09 d$ & $0.15 \pm 0.02 \mathrm{~s}$ & $0.10 \pm 0.01 \mathrm{ij}$ & $0.66 \pm 0.12 \mathrm{Imo}$ \\
\hline 7 & PAC & $0.07 \pm 0.01 \mathrm{k}$ & $0.39 \pm 0.09 \mathrm{klmno}$ & $0.02 \pm 0.00 \mathrm{~lm}$ & $0.43 \pm 0.06 \mathrm{pq}$ \\
\hline 8 & PAL & $0.07 \pm 0.01 \mathrm{k}$ & $0.37 \pm 0.05 \mathrm{mno}$ & $0.02 \pm 0.01 \mathrm{Im}$ & $0.44 \pm 0.13 \mathrm{opq}$ \\
\hline 9 & PSR & $0.69 \pm 0.06 \mathrm{~d}$ & $0.30 \pm 0.05 \mathrm{opq}$ & $0.07 \pm 0.02 \mathrm{k}$ & $0.53 \pm 0.06 \mathrm{mnop}$ \\
\hline 10 & PAB & $0.11 \pm 0.03 \mathrm{jk}$ & $0.60 \pm 0.15$ cdefghijk & $0.03 \pm 0.01 \mathrm{Im}$ & $0.41 \pm 0.08 \mathrm{pq}$ \\
\hline 11 & PAA & $0.12 \pm 0.00 \mathrm{j}$ & $0.52 \pm 0.10 \mathrm{ijkm}$ & $0.03 \pm 0.001$ & $0.62 \pm 0.16$ Imnop \\
\hline 12 & PVR & $1.22 \pm 0.11 \mathrm{c}$ & $0.92 \pm 0.13 b$ & $0.04 \pm 0.011$ & $0.35 \pm 0.05 \mathrm{qr}$ \\
\hline 13 & $\mathrm{PO}$ & $0.37 \pm 0.11$ ef & $0.53 \pm 0.14 \mathrm{ghi}$ & $0.02 \pm 0.00 \mathrm{~m}$ & $0.20 \pm 0.03 \mathrm{~s}$ \\
\hline 14 & PSE & $1.72 \pm 0.15 b$ & $0.63 \pm 0.12$ cdefghij & $0.07 \pm 0.01 \mathrm{k}$ & $0.45 \pm 0.02$ nop \\
\hline 15 & PAZ & $0.12 \pm 0.03 \mathrm{jk}$ & $0.59 \pm 0.11$ cdefghij & $0.02 \pm 0.00 \mathrm{~m}$ & $0.26 \pm 0.06 r s$ \\
\hline 16 & PVB & $0.21 \pm 0.03 \mathrm{fgh}$ & $0.53 \pm 0.22$ fghijklm & $0.12 \pm 0.03 \mathrm{ghi}$ & $1.09 \pm 0.12 \mathrm{ij}$ \\
\hline 17 & PVC & $0.13 \pm 0.01 j$ & $0.51 \pm 0.05 \mathrm{jk}$ & $0.18 \pm 0.02$ def & $0.97 \pm 0.07 \mathrm{j}$ \\
\hline 18 & PVF & $0.24 \pm 0.04 \mathrm{fgh}$ & $0.35 \pm 0.07 \mathrm{mnop}$ & $0.22 \pm 0.02 \mathrm{bcd}$ & $1.32 \pm 0.11 \mathrm{ghi}$ \\
\hline 19 & PVN & $0.14 \pm 0.04 \mathrm{ij}$ & $0.55 \pm 0.07$ efghij & $0.09 \pm 0.03 \mathrm{jk}$ & $1.01 \pm 0.24 \mathrm{ijk}$ \\
\hline 20 & PVA & $0.30 \pm 0.06 \mathrm{f}$ & $0.70 \pm 0.11$ cefgi & $0.10 \pm 0.02 \mathrm{ijk}$ & $1.51 \pm 0.43 \mathrm{fghi}$ \\
\hline 21 & PVK & $0.15 \pm 0.03 \mathrm{ij}$ & $0.49 \pm 0.06 \mathrm{jk}$ & $0.14 \pm 0.03 \mathrm{fg}$ & $1.7 \pm 0.25$ defg \\
\hline 22 & PVP & $0.32 \pm 0.04 \mathrm{f}$ & $0.57 \pm 0.01$ defghij & $0.13 \pm 0.03 \mathrm{gh}$ & $1.07 \pm 0.19 \mathrm{ij}$ \\
\hline 23 & PVT & $0.32 \pm 0.04 \mathrm{f}$ & $0.72 \pm 0.05 \mathrm{cf}$ & $0.13 \pm 0.01 \mathrm{~g}$ & $1.01 \pm 0.06 \mathrm{j}$ \\
\hline 24 & MSX & $0.13 \pm 0.02 \mathrm{j}$ & $0.32 \pm 0.05$ nop & $0.25 \pm 0.06 \mathrm{bc}$ & $2.71 \pm 0.27 b$ \\
\hline 25 & MSZ & $0.19 \pm 0.03 \mathrm{ghi}$ & $0.25 \pm 0.06 \mathrm{pqr}$ & $0.11 \pm 0.02$ ghij & $1.16 \pm 0.25$ hij \\
\hline 26 & MSY & $0.06 \pm 0.02 \mathrm{k}$ & $0.06 \pm 0.01 \mathrm{t}$ & $0.47 \pm 0.09 \mathrm{~b}$ & $2.73 \pm 0.83 \mathrm{bcd}$ \\
\hline 27 & $\mathrm{MSH}$ & $0.18 \pm 0.03 \mathrm{hi}$ & $0.24 \pm 0.03 \mathrm{qr}$ & $0.15 \pm 0.03 \mathrm{efg}$ & $1.78 \pm 0.37$ cdef \\
\hline 28 & MSM & $0.24 \pm 0.04 \mathrm{fgh}$ & $0.38 \pm 0.01 \mathrm{Imn}$ & $0.15 \pm 0.02 \mathrm{fg}$ & $1.66 \pm 0.23$ defgh \\
\hline 29 & MSG & $0.23 \pm 0.05 \mathrm{fgh}$ & $0.19 \pm 0.04 \mathrm{rs}$ & $0.22 \pm 0.04 \mathrm{bc}$ & $1.51 \pm 0.20$ efgh \\
\hline 30 & MG & $0.28 \pm 0.05 f$ & $0.48 \pm 0.07 \mathrm{jkm}$ & $0.18 \pm 0.02$ cdef & $1.87 \pm 0.20 \mathrm{cdef}$ \\
\hline 31 & MSC & $0.28 \pm 0.07 \mathrm{fg}$ & $0.27 \pm 0.03 p q$ & $0.18 \pm 0.02$ def & $2.20 \pm 0.23 c$ \\
\hline 32 & MS & $0.08 \pm 0.01 \mathrm{k}$ & $0.52 \pm 0.05$ hijk & $0.12 \pm 0.01 \mathrm{ghi}$ & $2.00 \pm 0.18 \mathrm{cdf}$ \\
\hline 33 & $A D$ & $0.76 \pm 0.07 \mathrm{~d}$ & $0.67 \pm 0.02 \mathrm{cfg}$ & $0.29 \pm 0.09 b$ & $2.51 \pm 0.76 \mathrm{bcdf}$ \\
\hline 34 & ADV & $1.38 \pm 0.12 c$ & $1.26 \pm 0.22 \mathrm{a}$ & $0.21 \pm 0.03 \mathrm{bcd}$ & $1.93 \pm 0.32 \mathrm{cdef}$ \\
\hline
\end{tabular}

Results are expressed as mean \pm SD $(n=4)$. Means with a common letter do not differ at $p<$ 0.05 .

\section{DISCUSSION}

Such an extensive comparison of the ornamental and/or energy grasses with $\mathrm{Cd} / \mathrm{Zn}$ hyperaccumulators in the same growing conditions and using in-situ historically contaminated soil has not been previously reported. The grasses used covered 4 genera and included cultivars/species within these genera. Their potential for both 
phytoextraction and phytostabilization for $\mathrm{Cd}$ and $\mathrm{Zn}$ was compared. Substantial $\mathrm{Cd}$ amounts were accumulated in shoots of PPP and PAP, similar to those of the $\mathrm{Cd} / \mathrm{Zn}$ hyperaccumulator NC and greater than that of Cd hyperaccumulator ILC, respectively; in shoots of ADV Zn amounts were higher than for NC. Cadmium BCFRs for 19 out of 32 grasses exceeded 1 but Zn BCFR exceeded one only for PPP. Pennisetum purpureum 'Purple' exhibited the most potential for phytoextraction of $\mathrm{Cd}$ and phytostabilization of both $\mathrm{Cd}$ and $\mathrm{Zn}$. A. donax var. versicolor was the best candidate for $\mathrm{Zn}$ phytoextraction. There were very large variations between grasses in terms of both remediation mechanisms, underlying the value in screening for their potential and further research into the basis of this variation.
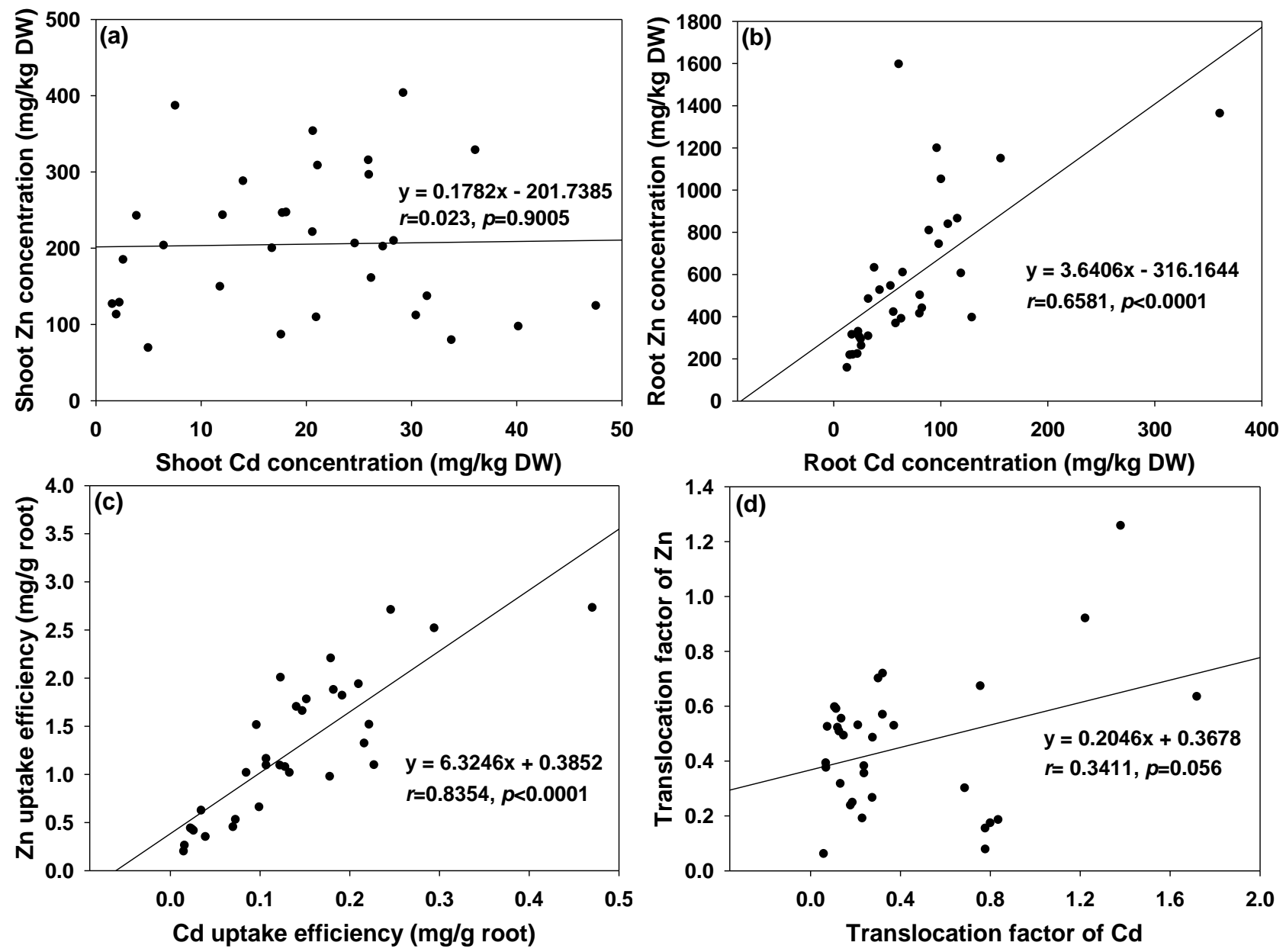

Fig. 8. Correlations between $\mathrm{Cd}$ and $\mathrm{Zn}$ as for their shoot concentrations (a), root concentrations (b), uptake efficiencies (c), and translocation factors (d) for 32 grasses.

Though shoot Cd concentrations in the Pennisetum spp. PPP and PAP were lower than NC and ILC, this was counter-balanced by their large SW (Figs. 1a, 2a, 4a). Similar results were obtained in other studies. For example though $\mathrm{Cd}$ concentrations in aerial part of Pennisetum sp. were lower than the $\mathrm{Cd}$ hyperaccumulator (Sedum plumbizincicola), and $\mathrm{Cu}$ concentrations lower than in the $\mathrm{Cu}$ tolerant Elsholtzia splendens, Pennisetum sp. accumulated and removed more $\mathrm{Cd}$ and $\mathrm{Cu}$ due to its much larger biomass (Xu et al. 2019). However, soil Cd concentration was very low $(<0.42$ $\mathrm{mg} / \mathrm{kg}$ ) and $1 \%$ hydroxyapatite was added in that study. In a study by $\mathrm{Hu}$ et al. (2018), 
$\mathrm{Cd}$ amounts in shoots and roots of Pennisetum sinese removed 1.56 and $0.30 \mathrm{mg}$ per plant respectively when soil $\mathrm{Cd}$ concentration was $8 \mathrm{mg} / \mathrm{kg}$, removal rates higher than those obtained herein even though the soil Cd contamination was greater. This apparent inconsistency may be attributed to the smaller biomass, which was probably due to higher Cd concentration in soil or limited pot soil volume in the present study (Table 1, Fig. 4), or metal availability due to differences in soil $\mathrm{pH}$. It was also reported that Pennisetum purpureum could accumulate 0.52 and $0.58 \mathrm{mg} \mathrm{Cd}$ in shoots and roots respectively per plant without any $\mathrm{N}$ fertilizer or chelating agent addition (Chen et al. 2017). Accumulations of $\mathrm{Cd}$ and $\mathrm{Zn}$ in shoots of PAP were up to 0.62 and $8.2 \mathrm{mg}$ per plant, with BCFS of 5.9 and 2.7 respectively, when $\mathrm{Cd}$ and $\mathrm{Zn}$ concentrations of soil were 8 and 600 $\mathrm{mg} / \mathrm{kg}$ (Zhang et al. 2010). These studies did not include a hyperaccumulator for reference and a limited range of grasses were compared, but their findings are broadly in line with those of the present study.

Switchgrass can have an aboveground annual yield of up to $20 \mathrm{Mg} / \mathrm{ha}$ (Singh et al. 2010). Switchgrass is tolerant to $\mathrm{Cd}$ and suitable for its phytoextraction in situ due to this high yield and ease of cultivation (Reed et al. 2002; Chen et al. 2012). There were eight switchgrass cultivars investigated in the present study (Table 1). Three cultivars, 'Alamo', 'Kanlow' and 'Blackwell', used herein, were also investigated by Sun et al. (2018). Their ranking of Cd concentrations in shoot or root among the three cultivars differed from the present findings, but that of $\mathrm{Cd}$ accumulation in shoot and root were similar (Figs. 2 and 4). For 'Alamo' a higher Cd translocation factor and lower Cd concentration in shoot and root than 'Cave-in-Rock' was consistent with a previous study (Liu et al. 2016). Higher biomass and higher Cd amounts in shoots of Alamo than Blackwell was also obtained by Chen et al. (2011), who suggested that Alamo had greater potential than Blackwell for Cd phytoextraction.

There are large differences in uptake capacity and tolerance to $\mathrm{Cd} / \mathrm{Zn}$ between different species of Miscanthus (Pidlisnyuk et al. 2014; Barbosa et al. 2015; Zhang et al. 2015; Guo et al. 2016). Cadmium concentrations in shoots and roots for three Miscanthus spp. varied by factors of 6.7 and 3.0 respectively; $M$. sinensis had the highest and intermediate concentrations of $\mathrm{Cd}$ in root and shoot, respectively, and MS had the lowest Cd concentrations in both shoot and root, among the three species (Guo et al. 2016). In the present study, shoot concentration, root concentration, and $\mathrm{TF}$ of $\mathrm{Cd}$ in the eight Miscanthus species/cultivars varied in the ranges $11.8-29.3 \mathrm{mg} / \mathrm{kg}, 64.9-361.3 \mathrm{mg} / \mathrm{kg}$, and $0.06-0.28$, respectively, at a soil total $\mathrm{Cd} 48.1 \mathrm{mg} / \mathrm{kg}$. In another study investigating $\mathrm{MS}$, its shoot concentration, root concentration and $\mathrm{TF}$ of $\mathrm{Cd}$ varied in the ranges $0.92-$ $18.36 \mathrm{mg} / \mathrm{kg}, \quad 2.34-64.77 \mathrm{mg} / \mathrm{kg}$, and $0.50-0.29$, respectively, at soil total $\mathrm{Cd}$ concentrations from 1 to $100 \mathrm{mg} / \mathrm{kg}$ (Zhang et al. 2015), consistent with results reported here. In addition, reported tolerance of Miscanthus spp. to heavy metals varied in the literature (Pidlisnyuk et al. 2014; Guo et al. 2016). Three Miscanthus spp. exhibited different growth and physiological responses after treated with $0-200 \mu \mathrm{mol} / \mathrm{L} \mathrm{Cd}$ in solutions. In the present study, only MSY showed marked sensitivity to $\mathrm{Cd} / \mathrm{Zn}$ contamination. The MS tolerance to and low accumulation of $\mathrm{Cd}$ may in part be due to Cd induced malate secretion (Guo et al. 2016, 2017). Results by Zhang et al. (2015) also suggested that MS had a strong ability to tolerate Cd but a poor ability to translocate $\mathrm{Cd}$ from root to shoot (Pidlisnyuk et al. 2014). Regarding Zn, it was reported that the aerial biomass and $\mathrm{Zn}$ accumulation of $\mathrm{MG}$ was much higher than $M$. sinensis, consistent with results herein, although the reported higher shoot $\mathrm{Zn}$ concentration and $\mathrm{TF}$ for $M$. sinensis than for MG differ from the present results (Fig. 3, Table 3) (Barbosa et al. 2015). The 
low TF of $M$. sinensis obtained by Lee et al. (2014) is similar to findings herein, indicating that $M$. sinensis mainly accumulated $\mathrm{Cd}$ and $\mathrm{Zn}$ in roots. The high $\mathrm{Zn}$ concentrations in shoots of MS were consistent with the results by Li et al. (2014).

Arundo donax is highly tolerant to heavy metals. It has a large biomass and a fast growth rate even under abiotic stresses. This species mainly accumulated heavy metals in belowground structures with BCFR and TF values lower than 1 when planted in contaminated municipal sludge, landfill soils, and mine sites (Papazoglou et al. 2005; Guo and Miao 2010; Nsanganwimana et al. 2014). In addition to being highly tolerant to heavy metals such as $\mathrm{Zn}$ and $\mathrm{Pb}, \mathrm{AD}$ can accumulate high $\mathrm{Zn}$ concentrations (Barbosa et al. 2015), as in the present study. In contrast, here ADV, which has been rarely evaluated for phytoremediation, had high shoot concentrations, high accumulation and TF $(>1)$ of $\mathrm{Cd}$ and $\mathrm{Zn}$ in comparison to $\mathrm{AD}$ (Figs. 2, 3, 4, 5, Table 3). A. donax var. versicolor exhibited a substantial capacity for phytoextraction of soil $\mathrm{Cd}$ and $\mathrm{Zn}$.

Iris lacteal, considered a $\mathrm{Cd}$ hyperaccumulator, is reported to be highly tolerant to $\mathrm{Cd}$ and have a potential capacity to phytostabilize and phytoextract soil $\mathrm{Cd}$ (Han et al. 2007; Guo et al. 2017). In a nutrient solution with Cd concentration of 0 to $50 \mathrm{mg} / \mathrm{L}$ for 21 days, ILC had Cd concentrations in shoots and roots up to 218 and $2714 \mathrm{mg} / \mathrm{kg}$ respectively, without exhibiting any toxicity symptom or growth reduction (Guo et al. 2017). Iris lactea had higher Cd concentration in shoots than in the grasses in the present study, indicating its strong phytoextractive capacity, though shoot $\mathrm{Cd}$ concentration was less than the $100 \mathrm{mg} / \mathrm{kg}$ threshold of hyperaccumulator status (Fig. 2a). The presently observed Cd TF of less than one is consistent with other studies (Han et al. 2007; Guo et al. 2017). It is notable however that ILC had low $\mathrm{Zn}$ concentrations in shoots and roots, highlighting the difficulties associated with phytoremediation of soils with multi-element contamination.

Plants with BCFSs and TFs $>1$ are usually considered suitable for phytoextraction (McGrath and Zhao 2003; Liu et al. 2018). However, fast growing nonhyperaccumulators that have large biomass are well-adapted to stresses and have practical cropping characteristics may be more suitable for phytoextraction, since their larger aerial biomass can more than compensate for the lower concentration of heavy metals. In the present study, PPP and PAP accumulated similar amounts of $\mathrm{Cd}$ in shoots to the hyperaccumulator NC, and more than ILC, even though both PPP and PAP had lower TF $(<1)$ and lower BCFS $(\leq 1)$ (Fig. 6a, Table 3). Likewise, ADV with low BCFS $(<1)$ and high TF $(>1)$ accumulated 55.4\% more shoot $\mathrm{Zn}$ than NC. In addition, there are multiple uses for these high yielding lignocellulosic grasses, such as the production of energy (second generation ethanol and biofuels), paper pulp, building materials and adsorbents; they also have a role in soil erosion control and landscape restoration (Ververis et al. 2004; Pirozzi et al. 2010; Nasso et al. 2011; Gong et al. 2018; Pogrzeba et al. 2018). Thus, utilization of these grasses may promote heavy metal phytoextraction of soil whilst generating income.

Plants with a high BCFR $(>1)$ and low TF $(<1)$ are considered to be suitable for phytostabilization (Yoon et al. 2006; Cheraghi et al. 2011). There were 19 out of 32 grasses with BCFR $>1$ and $\mathrm{TF}<1$ for Cd (Fig. 6b, Table 3). All species/cultivars of Panicum virgatum as well as Miscanthus having high BCFRs $(>1)$ and low TFs $(<1)$ suggested that the two had more potential capacity in soil $\mathrm{Cd}$ phytostabilization than other genera on the whole. In addition, several grasses such as PP, PSI and PVR with high root $\mathrm{Cd}$ accumulation but $\mathrm{RCFRs}<1$ could also potentially stabilize soil $\mathrm{Cd}$ due to their well-developed root systems (RW, RL and RSA) (Figs. 1b, S6, Table S1). 
Regarding Zn, NC with a high BCFS $>1$ and high $\mathrm{TF}>1$ was potentially suitable for phytoextraction of Zn (Fig. 7a, Table 3). Only PPP with a high BCFR not less than one and low $\mathrm{TF}<1$ had the potential for phytostabilization (Fig. 7b, Table 3). Furthermore, PPP accumulated the most $\mathrm{Zn}$ in roots among the cultivars/species tested (Fig. 5b). Therefore, although many of the tested ornamental and/or energy grasses in the present study had the potential to phytostabilization soil Cd combined with many of the other benefits described above, only PPP also had phytostabilization potential for soil Zn.

There were positive correlations for root concentrations and UEs per gram root between $\mathrm{Cd}$ and $\mathrm{Zn}$, but not for shoot concentrations and TFs (Fig. 8a, b, c, d). This may imply that sorption of $\mathrm{Cd}$ by roots of these grasses potentially shares the channel of $\mathrm{Zn}$, while the translocation of $\mathrm{Cd}$ with $\mathrm{Zn}$ from root to shoot may be more complicated. Cadmium and $\mathrm{Zn}$ have the same electron configuration and similar chemical properties. Thus, key transporters such as ZRT and IRT-like proteins responsible for Zn transport are also able to transport Cd (Fulekar et al. 2009; Jin et al. 2010). Cadmium could enter plant roots via the $\mathrm{Zn}$ channel and compete with $\mathrm{Zn}$ for binding sites on the root surface (Rizwan et al. 2019). Therefore, under the same conditions, it is reasonable that plants having strong sorptive capacity of $\mathrm{Zn}$ by root could easily sorb $\mathrm{Cd}$, and vice versa. However, other processes such deposition in apoplast of root cortex, inhibition by casparian strip and endodermis wall, complexation by phytochelatins, compartmentalization in vacuole and competition for binding sites of transporters with $\mathrm{Zn}^{2+}, \mathrm{Ca}^{2+}$ and $\mathrm{Fe}^{2+}$ may disrupt root sorption for $\mathrm{Cd}$. The influence of related factors and mechanisms affecting translocation of $\mathrm{Cd}$ from root to shoot, including loading and unloading between phloem and xylem, and transpiration traction remain unclear (Wang et al. 2015). Cadmium transport is affected by complex interactions and competition between $\mathrm{Cd}$ and $\mathrm{Zn}$ for transporter binding sites in loading or unloading processes, which may explain the lack of correlation for shoot concentrations and TFs between $\mathrm{Zn}$ and $\mathrm{Cd}$ (Fig. 8c, d).

This study did not have as a primary aim the elucidation of mechanisms explaining differences in performance between grasses. Nevertheless, certain plant characteristics explained a very large proportion of the variation in this performance. The correlation matrix between $\mathrm{Cd} / \mathrm{Zn}$ accumulation and root parameters showed that RL, RSA and RW were all positively correlated with $\mathrm{Cd}$ and $\mathrm{Zn}$ amounts accumulated in root and the whole plant, and with shoot Cd amount ( $p<0.01)$ (Table S1). These findings indicate that rooting characteristics (RL, RSA and RW) also were likely factors influencing $\mathrm{Cd}$ and $\mathrm{Zn}$ accumulation in grasses. The greatest $\mathrm{Cd}$ amount accumulated in shoots of PPP among grasses may be attributed to its long RL, large RSA and RW, in addition to large SW (Figs. 1 and S6, Table S1). The highest PPP accumulation of Zn in roots among the cultivars/species tested (Fig. 5b) may also be attributable to the longest RL, large RSA, and RW (Figs. 1b and S6, Table S1). On the other hand, concentrations of $\mathrm{Cd} / \mathrm{Zn}$ in shoots or roots were also key factors influencing the $\mathrm{Cd} / \mathrm{Zn}$ accumulation in addition to plant parameters. Multiple linear regressions suggested that the ratio of RL to $\mathrm{RW}(\mathrm{RL} / \mathrm{RW})$ was a significant factor favoring $\mathrm{Cd}$ concentrations in shoots and roots and root $\mathrm{Zn}$ concentrations. However, greater $\mathrm{RW}$ went against shoot $\mathrm{Zn}$ concentrations (Table S2). This may because that the increased root growth allowed more $\mathrm{Zn}$ to be stored within roots thereby decreasing shoot $\mathrm{Zn}$ concentrations.

The experimental set-up involving growing plants in pots is likely to have constrained the growth and metal accumulation of the large biomass grasses such as PPP, $\mathrm{PAP}$, and ADV. Thus, although they accumulated $\mathrm{Cd}$ or $\mathrm{Zn}$ in shoots at levels similar to 
or larger than the smaller biomass hyperaccumulators NC and ILC, their phytoextraction potential may have been underestimated. The short-term (3 months' growth in soil) is a limitation in the present study. A further focus on a more limited range of plants with larger pots or even field plots and multiple harvests is needed; multiple harvests would indicate in particular whether annual rates of phytoextraction could be sustained. It is worth noting also that heavy metal accumulation in energy grasses grown at $100 \mathrm{mg}$ $\mathrm{Cd} / \mathrm{kg}$ soil could enhance biomass enzymatic saccharification and hexoses, and bioethanol yields through increasing hemicellulose and pectin contents and reducing cellulose levels (Cheng et al. 2018). Thus, phytoremediation of heavy metal contaminated soil using energy grasses has considerable potential to couple soil remediation with production, making better use of the contaminated land.

\section{CONCLUSIONS}

1. High yielding energy grasses such as PPP, PAP, and ADV accumulated similar or more $\mathrm{Cd} / \mathrm{Zn}$ in shoots than hyperaccumulators tested, though their shoot $\mathrm{Cd} / \mathrm{Zn}$ concentrations were lower. Grasses with high growth are potentially more effective than hyperaccumulators in soil remediation due to the compensation of large biomass for lower metal concentrations and also their well-developed root systems.

2. Excluding MSY and the two hyperaccumulators, biomass, $\mathrm{Cd}$ and $\mathrm{Zn}$ concentrations, and $\mathrm{Cd}$ and $\mathrm{Zn}$ amounts in shoots varied by factors of 14.2, 29.8, 5.9, 281, and 29.9, respectively. Those of roots varied by factors of 18.9, 12.3, 10.2, 10.9, and 32.5, respectively; TFs of $\mathrm{Cd}$ and $\mathrm{Zn}$ varied by factors of 24.7 and 16.3, respectively. There were also large variations within species/genus for $\mathrm{Cd} / \mathrm{Zn}$ concentrations and accumulated amounts underlining the value of this screening investigation

3. Grasses PPP and ADV were the best candidates for $\mathrm{Cd}$ and $\mathrm{Zn}$ extraction, respectively. Most grasses could potentially stabilize soil $\mathrm{Cd}$ by root sequestration. Panicum virgatum as well as Miscanthus were more suitable for soil $\mathrm{Cd}$ phytostabilization compared with other grasses tested. Pennisetum purpureum 'Purple' is proposed as a comprehensive candidate in phytoextraction and phytostabilization for soil $\mathrm{Cd}$ and phytostabilization for soil $\mathrm{Zn}$.

4. Regarding soils contaminated by both $\mathrm{Cd}$ and $\mathrm{Zn}, \mathrm{NC}$ and $\mathrm{ADV}$ were prime candidates in phytoextraction, and PP, PSI, PPP were better for phytostabilization. The high $\mathrm{Cd}$ but low $\mathrm{Zn}$ concentrations for the $\mathrm{Cd}$ hyperaccumulator ILC indicates the difficulties in successful phytoremediation of soils with multi-metal contamination.

5. In addition to the considerable effectiveness in soil remediation, the utility of energy grasses in production of bioenergy, paper pulp, building materials, etc. means that soil remediation using these grasses can integrate remediation with economic outcomes, making the approach much easier to apply and to be accepted. 


\section{ACKNOWLEDGMENTS}

The authors are grateful for the support of the Beijing Academy of Agriculture and Forestry Sciences, Grant Numbers KJCX20170411, KJCX20170207 and KJCX20180707, and the National Natural Science Foundation of China, Grant Number 41501336. The authors thank Dr. Chao Chen for his help in the verification and revision of Latin names of plants.

\section{REFERENCES CITED}

Barbosa, B., Boleo, S., Sidella, S., Costa, J., Duarte, M. P., Mendes, B., Cosentino, S. L., and Fernando, A. L. (2015). "Phytoremediation of heavy metal-contaminated soils using the perennial energy crops Miscanthus spp. and Arundo donax L.," BioEnergy Res. 8(4), 1500-1511. DOI: 10.1007/s12155-015-9688-9

Chen, B. C., Lai, H. Y., and Juang, K. W. (2012). "Model evaluation of plant metal content and biomass yield for the phytoextraction of heavy metals by switchgrass," Ecotoxicol. Environ. Saf. 80, 393-400. DOI: 10.1016/j.ecoenv.2012.04.011

Chen, B. C., Lai, H. Y., Lee, D. Y., and Juang, K. W. (2011). "Using chemical fractionation to evaluate the phytoextraction of cadmium by switchgrass from Cd-contaminated soils," Ecotoxicology 20(2), 409-418. DOI: 10.1007/s10646-010-0592-y

Chen, Y. H., Liu, M. J., Deng, Y. W., Zhong, F. L., Xu, B., Hu, L., Wang, M. K., and Wang, G. (2017). "Comparison of ammonium fertilizers, EDTA, and NTA on enhancing the uptake of cadmium by an energy plant, Napier grass (Pennisetum purpureum Schumach)," J. Soils Sediments 17(12), 2786-2796. DOI:

10.1007/s11368-017-1703-7

Chen, Z. Q., Liu, X., Ai, Y. W., Chen, J., Luo, X. M., Chen, J. Y., and Zhong, S. H. (2018). "Effects and mechanisms of revegetation modes on cadmium and lead pollution in artificial soil on railway rock-cut slopes," Sci. Total Environ. 644, $1602-$ 1611. DOI: 10.1016/j.scitotenv.2018.06.380

Cheng, S. Z., Yu, H., Hu, M., Wu, Y., Cheng, L. L., Cai, Q. M., Tu, Y. Y., Xia, T., and Peng, L. C. (2018). "Miscanthus accessions distinctively accumulate cadmium for largely enhanced biomass enzymatic saccharification by increasing hemicellulose and pectin and reducing cellulose CrI and DP," Bioresource Technol. 263, 67-74. DOI: 10.1016/j.biortech.2018.04.031

Cheraghi, M., Lorestani, B., Khorasani, N., Yousef, N., and Karami, M. (2011). "Findings on the phytoextraction and phytostabilization of soils contaminated with heavy metals," Biol. Trace Elem. Res. 144(1-3), 1133-1141. DOI: 10.1007\%2Fs 12011-009-8359-0

Erakhrumen, A. A. (2007). "Phytoremediation: An environmentally sound technology for pollution prevention, control and remediation in developing countries," Educ. Res. Rev. 2(7), 151-156.

Fulekar, M. H., Singh, A., and Bhaduri, A. M. (2009). "Genetic engineering strategies for enhancing phytoremediation of heavy metals," Afr. J. Biotechnol. 8(4), 529-535. DOI: 10.1016/j.mrgentox.2008.11.010

GB/T 15618-2018 (2018). "Soil environmental quality risk control standard for soil contamination of agricultural land," Standardization Administration of China, Beijing, China. 
Golda, S., and Korzeniowska, J. (2016). "Comparison of phytoremediation potential of three grass species in soil contaminated with cadmium," Environ. Prot. Nat. Resour. 27(1), 8-14. DOI: 10.1515/oszn-2016-0003

Gong, X. M., Huang, D. L., Liu, Y. G., Zeng, G. M., Wang, R. Z., Wei, J. J., Huang, C., $\mathrm{Xu}, \mathrm{P}$., Wan, J., and Zhang, C. (2018). "Pyrolysis and reutilization of plant residues after phytoremediation of heavy metals contaminated sediments: For heavy metals stabilization and dye adsorption," Bioresource Technol. 253, 64-71. DOI: 10.1016/j.biortech.2018.01.018

Guo, H. P., Feng, X., Hong, C. T., Chen, H. M., Zeng, F. R., Zheng, B. S., and Jiang, D. A. (2017). "Malate secretion from the root system is an important reason for higher resistance of Miscanthus sacchariflorus to cadmium," Physiol. Plant. 159(3), 340353. DOI: $10.1111 / \mathrm{ppl} .12526$

Guo, H. P., Hong, C. T., Chen, X. M., Xu, Y. X., Liu, Y., Jiang, D. A., and Zheng, B. S. (2016). "Different growth and physiological responses to cadmium of the three Miscanthus species," PloS One 11(4), 1534-1575. DOI:

10.1371/journal.pone.0153475

Guo, Q., Meng, L., Zhang, Y. N., Mao, P. C., Tian, X. X., Li, S. S., and Zhang, L. (2017). "Antioxidative systems, metal ion homeostasis and cadmium distribution in Iris lactea exposed to cadmium stress," Ecotoxicol. Environ. Saf. 139, 50-55. DOI: 10.1016/j.ecoenv.2016.12.013

Guo, Z. H., and Miao, X. F. (2010). "Growth changes and tissues anatomical characteristics of giant reed (Arundo donax L.) in soil contaminated with arsenic, cadmium and lead," J. Cent. South Univ. Technol. 17(4), 770-777. DOI: 10.1007/s11771-010-0555-8

Han, Y. L., Yuan, H. Y., Huang, S. Z., Guo, Z., Xia, B., and Gu, J. G. (2007). "Cadmium tolerance and accumulation by two species of Iris," Ecotoxicology 16(8), 557-563. DOI: 10.1007/s10646-007-0162-0

He, Z., Shentu, J., Yang, X., Baligar, V. C., Zhang, T., and Stoffella, P. J. (2015). "Heavy metal contamination of soils: Sources, indicators, and assessment," J. Environ. Indic. 9, 17-18.

Hu, L., Wang, R., Liu, X. L., Xu, B., Xie, T. H., Li, Y. Y, Wang, M. K., Wang, G., and Chen, Y. H. (2018). "Cadmium phytoextraction potential of king grass (Pennisetum sinese Roxb.) and responses of rhizosphere bacterial communities to a cadmium pollution gradient," Environ. Sci. Pollut. Res. 25(22), 21671-21681. DOI:

10.1007/s11356-018-2311-9

Huang, Y. Y., He, C. T., Shen, C., Guo, J. J., Mubeen, S., Yuan, J. G., and Yang, Z. Y. (2017). "Toxicity of cadmium and its health risks from leafy vegetable consumption," Food Funct. 8(4), 1373-1401. DOI: 10.1039/C6FO01580H

Jin, F., Wang, C., Lin, H. J., Shen, Y. O., Zhang, Z. M., Zhao, M. J., and Pan, G. T. (2010). "Heavy metal-transport proteins in plants: A review," Chin. J. Appl. Ecol. 21(7), 1875-1882. DOI: 10.13287/j.1001-9332.2010.0247

Khan, A., Khan, S., Khan, M. A., Qamar, Z., and Waqas, M. (2015). "The uptake and bioaccumulation of heavy metals by food plants, their effects on plants nutrients, and associated health risk: A review," Environ. Sci. Pollut. Res. 22(18), 13772-13799. DOI: $10.1007 / \mathrm{s} 11356-015-4881-0$

Lee, S. H., Ji, W. H., Lee, W. S., Koo, N. M., Koh, I. H., Kim, M. S., and Park, J. S. (2014). "Influence of amendments and aided phytostabilization on metal availability 
and mobility in $\mathrm{Pb} / \mathrm{Zn}$ mine tailings," J. Environ. Manage. 139, 15-21. DOI:

10.1016/j.jenvman.2014.02.019

Li, C., Xiao, B., Wang, Q. H., Yao, S. H., and Wu, J. Y. (2014). "Phytoremediation of Zn- and Cr-contaminated soil using two promising energy grasses," Water, Air, Soil Pollut. 225, 2027. DOI: 10.1007/s11270-014-2027-5

Liu, C. H., Lou, L. Q., Deng, J. X., Li, D. J., Yuan, S. X., and Cai, Q. S. (2016). "Morphphysiological responses of two switchgrass (Panicum virgatum L.) cultivars to cadmium stress," Grassl. Sci. 62, 92-101. DOI: 10.1111/grs.12119

Liu, L. W., Li, W., Song, W. P., and Guo, M. X. (2018). "Remediation techniques for heavy metal-contaminated soils: Principles and applicability," Sci. Total Environ. 633, 206-219. DOI: 10.1016/j.scitotenv.2018.03.161

Lorenz, S. E., Hamon, R. E., Holm, P. E., Domingues, H. C., Sequeira, E. M., Christensen, T. H., and McGrath, S. P. (1997). "Cadmium and zinc in plants and soil solutions from contaminated soils," Plant Soil 189(1), 21-31. DOI: 10.1023/A:1004214923372

Lu, R. K. (2000). Soil Agricultural Chemical Analysis Method, China Agriculture Science and Technique Press, Beijing, China.

McGrath, S. P., and Zhao, F. J. (2003). "Phytoextraction of metals and metalloids from contaminated soils," Curr. Opin. Biotechnol. 14(3), 277-282. DOI: 10.1016/S09581669(03)00060-0

Nasso, N. N. o. D., Roncucci, N., Triana, F., Tozzini, C., and Bonari, E. (2011). "Seasonal nutrient dynamics and biomass quality of giant reed (Arundo donax L.) and miscanthus (Miscanthus $\times$ giganteus Greef et Deuter) as energy crops," Ital. J. Agron. 6, 152-158. DOI: 10.4081/ija.2011.e24

Nordberg, G., Jin, T. Y., Bernard, A., Fierens, S., Buchet, J. P., Ye, T. T., Kong, Q. H., and Wang, H. F. (2002). "Low bone density and renal dysfunction following environmental cadmium exposure," Ambio 31(6), 478-481. DOI: 10.1579/0044-744731.6.478

Nsanganwimana, F., Marchand, L., Douay, F., and Mench, M. (2014). “Arundo donax L., a candidate for phytomanaging water and soils contaminated by trace elements and producing plant-based feedstock: A review," Int. J. Phytorem. 16(7-12), 982-1017. DOI: $10.1080 / 15226514.2013 .810580$

O'Connor, D., Peng, T., Zhang, J., Tsang, D. C. W., Alessi, D. S., Shen, Z., Bolan, N. S., and Hou, D. (2018). "Biochar application for the remediation of heavy metal polluted land: A review of in situ field trials," Sci. Total Environ. 619-620, 815-826. DOI: 10.1016/j.scitotenv.2017.11.132

Papazoglou, E. G., Karantounias, G. A., Vemmos, S. N., and Bouranis, D. L. (2005). "Photosynthesis and growth responses of giant reed (Arundo donax L.) to the heavy metals Cd and Ni," Environ. Int. 31(2), 243-249. DOI: 10.1016/j.envint.2004.09.022

Perronnet, K., Schwartz, C., and Morel, J. L. (2003). "Distribution of cadmium and zinc in the hyperaccumulator Thlaspi caerulescens grown on multicontaminated soil," Plant Soil 249(1), 19-25. DOI: 10.1023/a:1022560711597

Phusantisampan, T., Meeinkuirt, W., Saengwilai, P., Pichtel, J., and Chaiyarat, R. (2016). "Phytostabilization potential of two ecotypes of Vetiveria zizanioides in cadmiumcontaminated soils: Greenhouse and field experiments," Environ Sci Pollut Res. 23(19), 20027-20038. DOI: 10.1007/s11356-016-7229-5 
Pidlisnyuk, V., Stefanovska, T., Lewis, E. E., Erickson, L. E., and Davis, L. C. (2014). "Miscanthus as a productive biofuel crop for phytoremediation," Crit. Rev. Plant Sci. 33(1), 1-19. DOI: 10.1080/07352689.2014.847616

Pirozzi, D., Yousuf, A., Fagnano, M., Mori, M., Fiorentino, N., and Impagliazzo, A. (2010). "Lipids production by yeast grown on giant reed biomass," J. Biotechnol. 150, 167-168. DOI: 10.1016/j.jbiotec.2010.08.434

Pogrzeba, M., Rusinowski, S., and Krzyzak, J. (2018). "Macroelements and heavy metals content in energy crops cultivated on contaminated soil under different fertilizationCase studies on autumn harvest," Environ. Sci. Pollut. Res. 25(12), 12096-12106. DOI: 10.1007/s11356-018-1490-8

Reed, R. L., Sanderson, M. A., Allen, V. G., and Zartman, R. E. (2002). "Cadmium application and $\mathrm{pH}$ effects on growth and cadmium accumulation in switchgrass," Commun. Soil Sci. Plant Anal. 33(7-8), 1187-1203. DOI: 10.1081/css-120003881

Reeves, R. D., Baker, A. J. M., Jaffré, T., Erskine, P. D., Echevarria, G., and van der Ent, A. (2017). "A global database for plants that hyperaccumulate metal and metalloid trace elements," New Phytol. 218(2), 407-411. DOI: 10.1111/nph.14907

Rizwan, M., Ali, S., Adrees, M., Ibrahim, M., Tsang, D. C. W., Zia-Ur-Rehman, M., Zahir, Z. A., Rinklebe, J., Tack, F. M. G., and Ok, Y. S. (2017). "A critical review on effects, tolerance mechanisms and management of cadmium in vegetables," Chemosphere 182, 90-105. DOI: 10.1016/j.chemosphere.2017.05.013

Rizwan, M., Ali, S., Zia ur Rehman, M., and Maqbool, A. (2019). "A critical review on the effects of zinc at toxic levels of cadmium in plants," Environ. Sci. Pollut. Res. 26(7), 6279-6289. DOI: 10.1007/s11356-019-04174-6

Sarwar, N., Imran, M., Shaheen, M. R., Ishaque, W., Kamran, M. A., Matloob, A., Rehim, A., and Hussain, S. (2017). "Phytoremediation strategies for soils contaminated with heavy metals: Modifications and future perspectives," Chemosphere 171, 710-721. DOI: 10.1016/j.chemosphere.2016.12.116

Shahid, M., Dumat, C., Khalid, S., Niazi, N. K., and Antunes, P. M. C. (2016). "Cadmium bioavailability, uptake, toxicity and detoxification in soil-plant system," Rev. Environ. Contam. Toxicol. 241, 73-137. DOI: 10.1007/398_2016_8

Singh, A., Pant, D., Korres, N. E., Nizami, A. S., Prasad, S. H., and Murphy, J. D. (2010). "Key issues in life cycle assessment for ethanol production from lignocellulosic biomass: challenges and perspectives," Bioresource Technol. 101(13), 5003-5012. DOI: 10.1016/j.biortech.2009.11.062

Song, G., Yuan, S. X., Wen, X. H., Xie, Z. Y., Lou, L. Q., Hu, B. Y., Cai, Q. S., and Xu, B. (2018). "Transcriptome analysis of Cd-treated switchgrass root revealed novel transcripts and the importance of HSF/HSP network in switchgrass Cd tolerance," Plant Cell Rep. 37(11), 1485-1497. DOI: 10.1007/s00299-018-2318-1

Stephan, C. H., Courchesne, F., Hendershot, W. H., McGrath, S. P., Chaudri, A. M., Sappin-Didier, V., and Sauvé, S. (2008). "Speciation of zinc in contaminated soils," Environ. Pollut. 155(2), 208-216. DOI: 10.1016/j.envpol.2007.12.006

Sun, H., Xie, Y., Zheng, Y., Lin, Y., and Yang, F. (2018). "The enhancement by arbuscular mycorrhizal fungi of the $\mathrm{Cd}$ remediation ability and bioenergy qualityrelated factors of five switchgrass cultivars in Cd-contaminated soil," Peer J. 6(16), e4425. DOI: $10.7717 /$ peerj.4425

Ververis, C., Georghiou, K., Christodoulakis, N., Santas, P., and Santas, R. (2004). "Fiber dimensions, lignin and cellulose content of various plant materials and their 
suitability for paper production," Ind. Crops Prod. 19(3), 245-254. DOI:

10.1016/j.indcrop.2003.10.006

Wang, X. J., Wang, W. B., Yang, L., Jin, L., Song, Y., Jiang, S. J, and Qin, L. L. (2015). "Transport pathways of cadmium $(\mathrm{Cd})$ and its regulatory mechanisms in plant," Acta Ecol. Sin. 35(23), 7921-7929. DOI: 10.5846/stxb201404170754

Xu, L., Xing, X. Y., Liang, J. N., Peng, J. B., and Zhou, J. (2019). “In situ phytoremediation of copper and cadmium in a co-contaminated soil and its biological and physical effects," RSC Adv. 9(2), 993-1003. DOI: 10.1039/C8RA07645F

Yoon, J., Cao, X. D., Zhou, Q. X., and Ma, L. Q. (2006). “Accumulation of Pb, Cu, and $\mathrm{Zn}$ in native plants growing on a contaminated Florida site," Sci. Total Environ. 368(2-3), 456-464. DOI: 10.1016/j.scitotenv.2006.01.016

Zhang, J., Yang, S. Y., Huang, Y. J., and Zhou, S. B. (2015). "The tolerance and accumulation of Miscanthus sacchariflorus (Maxim.) Benth., an energy plant species, to cadmium," Int. J. Phytorem. 17(6), 538-545. DOI: 10.1080/15226514.2014.922925

Zhang, W. L., Du, Y., Zhai, M. M., and Shang, Q. (2014). "Cadmium exposure and its health effects: A 19-year follow-up study of a polluted area in China," Sci. Total Environ. 470-471, 224-228. DOI: 10.1016/j.scitotenv.2013.09.070

Zhang, X. F., Xia, H. P., Li, Z. A., Zhuang, P., and Gao, B. (2010). "Potential of four forage grasses in remediation of $\mathrm{Cd}$ and $\mathrm{Zn}$ contaminated soils," Bioresource Technol. 101(6), 2063-2066. DOI: 10.1016/j.biortech.2009.11.065

Zhao, F. J., Ma, Y., Zhu, Y. G., Tang, Z., and McGrath, S. P. (2015). "Soil contamination in China: Current status and mitigation strategies," Environ. Sci. Technol. 49(2), 750759. DOI: $10.1021 /$ es5047099

Zheng, R. L., Li, C., Sun, G. X., Xie, Z. B., Chen, J., Wu, J. Y., and Wang, Q. H. (2017). "The influence of particle size and feedstock of biochar on the accumulation of Cd, $\mathrm{Zn}, \mathrm{Pb}$, and As by Brassica chinensis L.," Environ. Sci. Pollut. Res. 24, 22340-22352. DOI: $10.1007 / \mathrm{s} 11356-017-9854-\mathrm{z}$

Zheng, R. L., Chen, Z., Cai, C., Wang, X., Huang, Y., Xiao, B., and Sun, G. (2013). "Effect of biochars from rice husk, bran, and straw on heavy metal uptake by potgrown wheat seedling in a historically contaminated soil," BioResources 8(4), 5965 5982. DOI: 10.15376/biores.8.4.5965-5982

Article submitted: October 17, 2019; Peer review completed: November 17, 2019; Revised version received: November 28, 2019; Accepted: December 1, 2019; Published: December 4, 2019.

DOI: 10.15376/biores.15.1.616-640 


\section{APPENDIX}

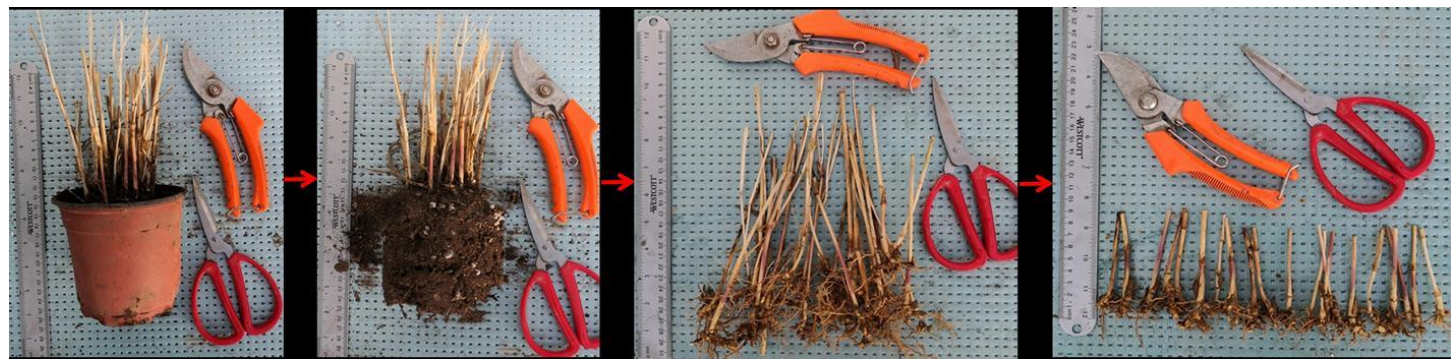

Fig. S1. Steps of cutting, taking Panicum virgatum 'Blackwell' as an example.

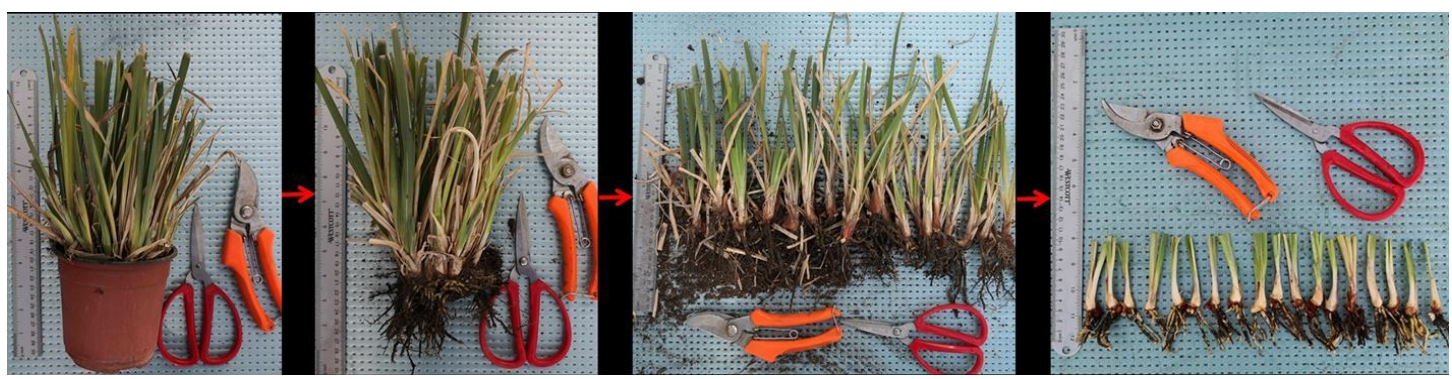

Fig. S2. Steps of tiller separation, taking Iris lactea var. chinensis as an example.
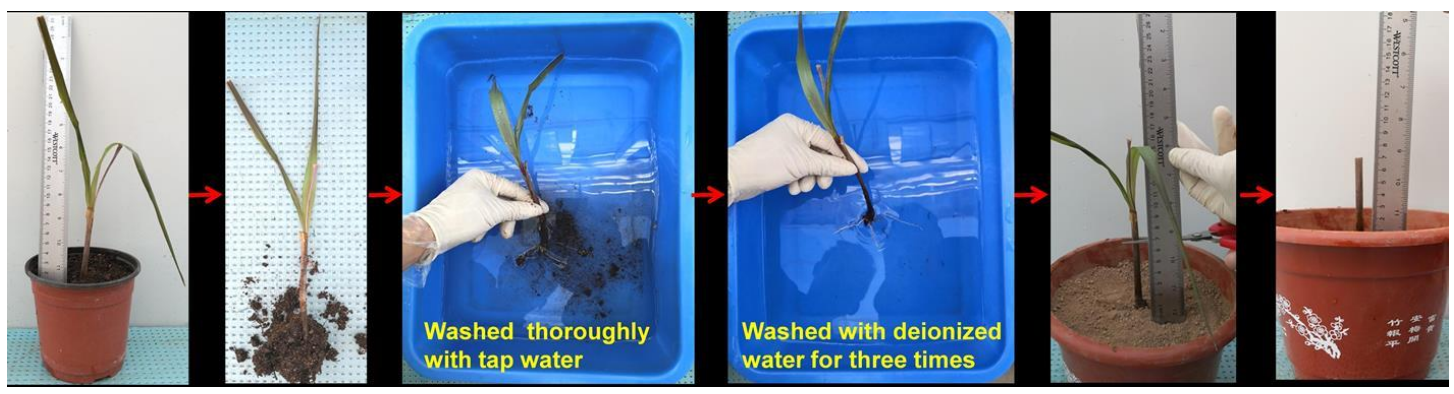

Fig. S3. After washed with deionized water, seedlings growing in peat for 3 weeks were transplanted into contaminated soils and clipped to 7-cm height, taking Pennisetum purpureum 'Purple' as an example.

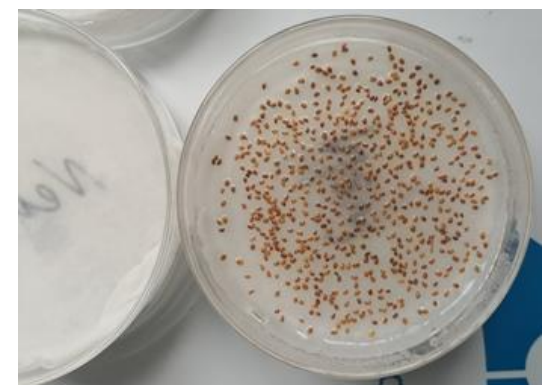

Fig. S4. Germination of Noccaea caerulescens seeds on moist filter paper in petri dish, keeping the water surface no more than half the diameter of the seed. 


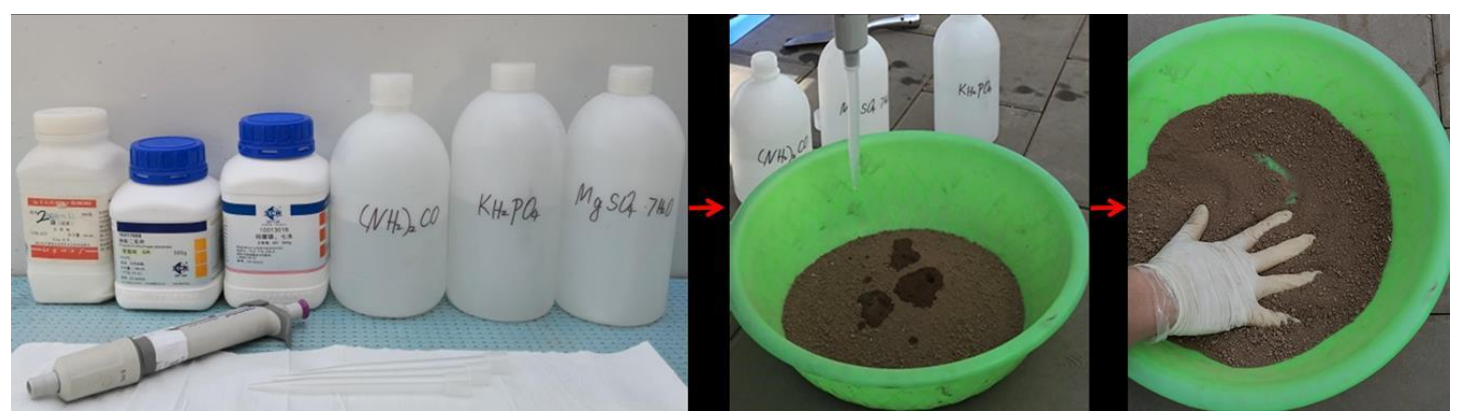

Fig. S5. Fertilizers urea, $\mathrm{KH}_{2} \mathrm{PO}_{4}$ and $\mathrm{MgSO}_{4} \cdot 7 \mathrm{H}_{2} \mathrm{O}$ were dissolved in deionized water respectively, added into soil ( $5 \mathrm{~mL}$ per pot for each reagent), and then soil was homogenized thoroughly.
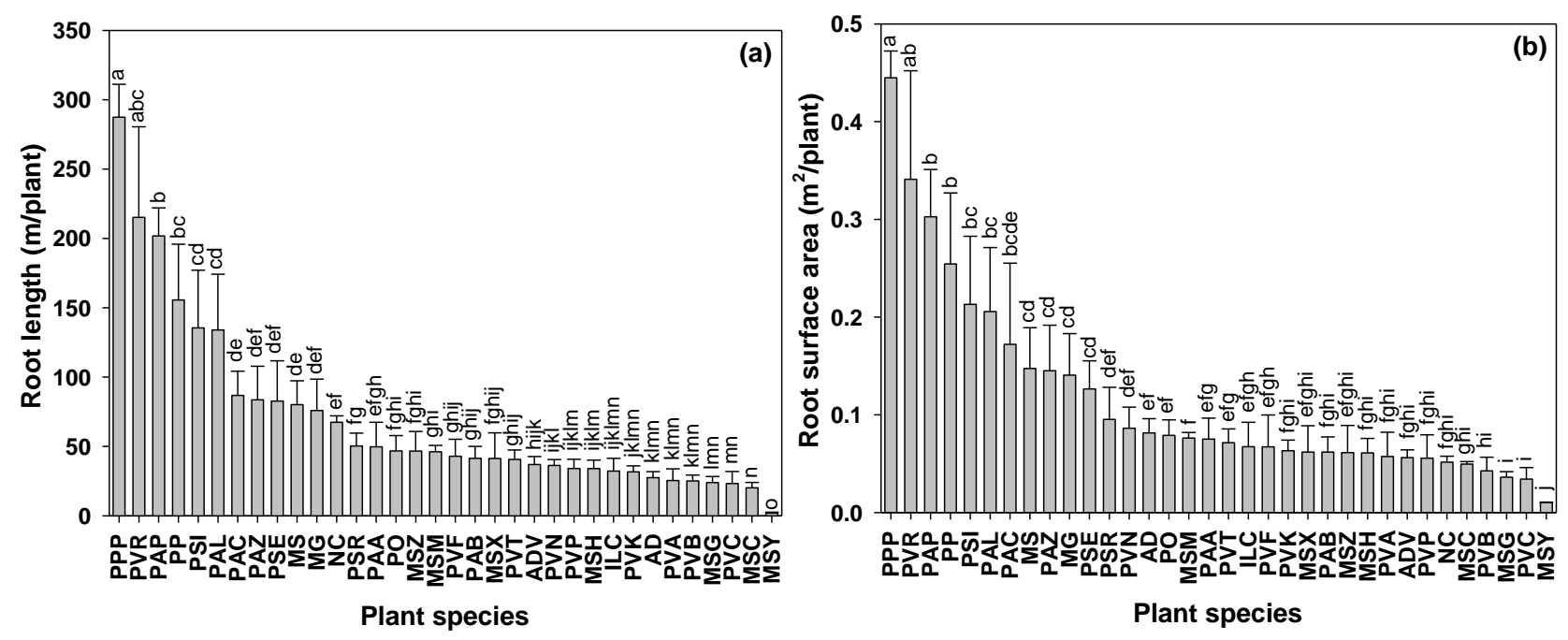

Fig. S6. Root length (a) and root surface area (b) of 32 grasses and 2 hyperaccumulators (mean $\pm \mathrm{SD}, \mathrm{n}=4$ ). Means with a common letter above columns do not differ at $p<0.05$. 
Table S1. Correlation Matrix (Pearson Correlation Coefficients) between Cd/Zn Accumulation in Shoot, Root and the Whole Plant and Root Parameters $(n=32)$ among 32 Grasses

\begin{tabular}{|c|c|c|c|c|c|c|}
\hline & \multicolumn{3}{|c|}{ Cd amount accumulation } & \multicolumn{3}{|c|}{ Zn amount accumulation } \\
\hline & The whole plant & Shoot & Root & The whole plant & Shoot & Root \\
\hline $\mathrm{RL}$ & $0.76^{\star \star \star}$ & $0.68^{* \star *}$ & $0.76^{* \star *}$ & $0.76^{\star \star \star}$ & 0.17 & $0.87^{* *}$ \\
\hline RSA & $0.75^{\star * *}$ & $0.67^{* * *}$ & $0.76^{* * *}$ & $0.78^{* * *}$ & 0.20 & $0.87^{* *}$ \\
\hline RW & $0.58^{* *}$ & $0.46^{\star *}$ & $0.69^{* * *}$ & $0.57^{* *}$ & 0.10 & $0.66^{\star *}$ \\
\hline $\mathrm{RL} / \mathrm{RW}$ & -0.02 & 0.02 & -0.1 & -0.08 & -0.19 & 0.01 \\
\hline
\end{tabular}

Table S2. Multiple Linear Regressions between Cd/Zn Concentrations in Shoots and Roots ([metal]s and [metal] $\mathrm{R}$ ) and Various Predictor Factors (SW, RW, RL, $\mathrm{RSA}, \mathrm{RL} / \mathrm{RW}$ ) among 32 Grasses. Based on Stepwise Regression Including only those Variables in Regression Equations that were Significant $(p<0.05)$

\begin{tabular}{|l|c|c|}
\hline \multicolumn{1}{|c|}{ Model } & $r$ value & Significance \\
\hline$[\mathrm{Cd}]_{\mathrm{S}}=2.058+1.457 \cdot \mathrm{SW}+0.279 \cdot \mathrm{RL} / \mathrm{RW}$ & 0.733 & $p<0.001$ \\
\hline$[\mathrm{Zn}]_{\mathrm{S}}=251.679-13.458 \cdot \mathrm{RW}$ & 0.442 & $p<0.001$ \\
\hline$[\mathrm{Cd}]_{\mathrm{R}=-14.856+3.403 \cdot \mathrm{RL} / \mathrm{RW}}$ & 0.837 & $p<0.001$ \\
\hline$[\mathrm{Zn}]_{\mathrm{R}=175.797+15.764 \cdot \mathrm{RL} / \mathrm{RW}}$ & 0.701 & $p<0.001$ \\
\hline
\end{tabular}

